OPEN ACCESS

Edited by:

Oliver Stork

Otto-von-Guericke University Magdeburg, Germany

Reviewed by:

Ezia Guatteo,

Parthenope University of Naples and

Fondazione Santa Lucia IRCCS,

Rome, Italy

David Ruskin,

Trinity College, United States

${ }^{*}$ Correspondence:

Ling Chen

lingchen@njmu.edu.cn

Received: 11 May 2017

Accepted: 24 July 2017

Published: 07 August 2017

Citation:

Zhang T, Chen T, Chen P, Zhang B,

Hong $J$ and Chen $L$ (2017)

MPTP-Induced Dopamine Depletion in Basolateral Amygdala via Decrease of D2R Activation Suppresses GABA

Receptors Expression and LTD Induction Leading to Anxiety-Like

Behaviors.

Front. Mol. Neurosci. 10:247. doi: 10.3389/fnmol.2017.00247

\section{MPTP-Induced Dopamine Depletion in Basolateral Amygdala via Decrease of D2R Activation Suppresses GABA Receptors Expression and LTD Induction Leading to Anxiety-Like Behaviors}

\author{
Tingting Zhang ${ }^{1,2}$, Tingting Chen ${ }^{1,2}$, Peipei Chen², Baofeng Zhang ${ }^{2}$, Juan Hong ${ }^{1,2}$ and \\ Ling Chen ${ }^{1,2 *}$
}

'State Key Lab of Reproductive Medicine, Nanjing Medical University, Nanjing, China, ${ }^{2}$ Department of Physiology, Nanjing Medical University, Nanjing, China

Anxiety disorders commonly occur in Parkinson's disease. Using field potential recording and patch-clamp recording, we evaluated influence of MPTP-reduced dopaminergic afferent in basolateral amygdala (BLA), a main region for affective regulation, on excitatory-inhibitory circuits and synaptic plasticity. Field excitatory postsynaptic potential (fEPSP) slopes at external capsule-BLA synapses were increased in MPTP-mice with decreases in paired-pulse facilitation and long-term potentiation amplitude, which were corrected by bath-application of D2R agonist quinpirole or cannabinoid type 1 receptors agonist WIN55,212-2, but not D1R agonist SKF38393. Compared to single waveform fEPSP in control mice, a multi-spike waveform fEPSP was observed in MPTP-mice with prolongation of duration and an increase in paired-pulse inhibition, which were recovered by BLA-injection of quinpirole for 2 days rather than bath-application. Density of GABA-evoked current (/GABA) in BLA principal neurons and $G_{A B A} R-\alpha 2$ subunit expression were reduced in MPTP-mice, which were recovered by administration of quinpirole. Decline of PKC phosphorylation in BLA of MPTP-mice was corrected by bath-application of quinpirole, but not SKF38393. In MPTP-mice, BLA-injection of quinpirole or PKC activator PMA could recover $G_{A B A} R$ expression, which was sensitive to PKC inhibitor GF109203X. The impairment of long-term depression (LTD) in MPTP-mice was rescued by bath-application of $\mathrm{GABA}_{A} R$ agonist muscimol or BLA-injection of quinpirole and PMA. Finally, BLA-injection of muscimol, quinpirole or PMA relieved anxiety-like behaviors in MPTP-mice. The results indicate that the MPTP-induced dopamine depletion in BLA principal neurons through reducing D2R-mediated PKC phosphorylation suppresses $G_{A B A} R$ expression and activity, which impairs $\mathrm{GABA}_{A}$ R-mediated inhibition and LTD induction leading to anxiety-like behaviors.

Keywords: dopaminergic receptor (DR), anxiety-like behaviors, basolateral amygdala (BLA), synaptic plasticity, $\mathrm{GABA}_{A}$ receptor $\left(\mathrm{GABA} \mathrm{A}_{\mathrm{B}} \mathrm{R}\right)$ 


\section{INTRODUCTION}

Parkinson's disease (PD) is a neurodegenerative disorder characterized by motor symptoms and a progressive loss of dopaminergic neurons (Braak et al., 2003; Rodriguez-Oroz et al., 2009). Anxiety disorders and depression commonly occur in PD patients, affecting up to $40 \%$ of patients at early stages of the disease (Walsh and Bennett, 2001). L-DOPA therapy can improve anxiety disorders in PD (Shin et al., 2014), suggesting that the affective disorders may be linked to a dopamine deficiency.

The basolateral nucleus of the amygdala (BLA), a main region for affective regulation, receives dense dopaminergic innervations from the ventral tegmental area (VTA). Using dual-labeling immunohistochemistry, Muller et al. (2009) have demonstrated that the principal neurons are the primary targets of the dopaminergic inputs to the BLA. The BLA principal neurons express the D1-like receptor (D1R) and D2-like receptor (D2R) (Pinto and Sesack, 2008). The activation of D1R increases excitability of BLA principal neurons, whereas the activation of D2R increases input resistance (Kroner et al., 2005). The activation of $D 2 R$ induces the release of postsynaptic endocannabinoids, which act as retrograde messengers via activation of cannabinoid type 1 receptors (CB1R) to inhibit glutamate release at cortico-striatal synapses (Yin and Lovinger, 2006). A large body of evidence indicates that hyperexcitability of the BLA principal neurons is associated with affective disorder in rodents and humans (Senn et al., 2014; Prager et al., 2016). The fear memory formation requires the induction of long-term potentiation (LTP) in the BLA principal neurons (Goosens and Maren, 2002), while long-term depression (LTD) is thought to facilitate the extinction of learned fear (Dalton et al., 2012). Recently, the impairment of LTD induction in BLA has been reported to cause the production of depressive-like behaviors (Zhang et al., 2017). By modulating the activity of amygdala neurons, dopaminergic neurons are known to control the expression of fear memory (Fadok et al., 2009; de la Mora et al., 2010). However, the influence of dopaminergic deficiency on the synaptic plasticity in BLA and affective behaviors remain to be elucidated.

The interaction between the dopaminergic, GABAergic, and glutamatergic inputs represents an important aspect of the functional regulation in BLA (Soghomonian and Chesselet, 2000). BLA output is controlled by a local feedback inhibition of GABAergic interneurons (Diaz et al., 2011). GABAergic interneurons can lead to a low resting firing rate of principal neurons (Woodruff and Sah, 2007). GABAergic disruption results in hyperexcitability of BLA principal neurons (Prager et al., 2016). The microinjection of $\mathrm{GABA}_{\mathrm{A}}$ receptors $\left(\mathrm{GABA}_{\mathrm{A}} \mathrm{R}\right)$ agonists and antagonists in amygdala can exert anxiolytic or anxiogeniclike effects, respectively (Barbalho et al., 2009). Dopamine is reported to control acquisition of fear memory by increasing inhibitory post-synaptic currents (IPSCs) in the lateral amygdala (Rosenkranz and Grace, 2002; Bissière et al., 2003).

The administration of neurotoxin 1-methyl-4-phenyl-1,2,3,6tetrahydropyridine (MPTP) in C57BL/6 mice reduces the dopaminergic fibers within the BLA (von Bohlen und Halbach et al., 2005) and causes the affective disorders (Schober, 2004).
The expression of $\mathrm{GABA}_{\mathrm{A}} \mathrm{R}$ in the rostral globus pallidus is decreased in MPTP-treated monkeys (Calon et al., 1995). The aim of the present study was to investigate the influence of the MPTP-induced dopamine depletion in BLA on D1R and D2R-mediated excitatory-inhibitory circuits, synaptic plasticity, and $\mathrm{GABA}_{\mathrm{A}} \mathrm{R}$ activity and expression. We further explored the association between the MPTP-induced dopamine depletion in BLA and production of affective disorders. Our results indicate that the MPTP-induced dopamine depletion in BLA through reducing D2R activation can suppress the $\mathrm{GABA}_{\mathrm{A}} \mathrm{R}$ expression and function, which causes the deficits in the $\mathrm{GABA}_{\mathrm{A}} \mathrm{R}$-mediated inhibitory circuit and LTD induction leading to the production of anxiety-like behaviors.

\section{MATERIALS AND METHODS}

\section{Animal Preparation}

All animal experiments were approved by Ethical Committee of the Nanjing Medical University and were performed in accordance with experimental animals guidelines established by the Laboratory Animal Research Institute. Eight-weekold (24-26 g) and 4-week-old (10-12 g) male C57BL/6 mice (Oriental Bio Service, Inc., Nanjing) were used at the beginning of the experiment. The mice were maintained under constant environmental conditions (temperature $23 \pm 2{ }^{\circ} \mathrm{C}$, humidity $55 \pm 5 \%$ and 12:12 h light/dark cycle) in Animal Research Center of Nanjing Medical University with free access to food and water. The mice received daily intraperitoneal (i.p.) injection of MPTP $(25 \mathrm{mg} / \mathrm{kg}$, measured as free base; Sigma-Aldrich, St. Louis, MO, United States) for 5 consecutive days (Crocker et al., 2003).

\section{Preparation and Administration of Drugs}

D1R antagonist SCH23390, D2R agonist quinpirole, AMPA receptor antagonist $\mathrm{CNQX}, \mathrm{GABA}_{\mathrm{A}} \mathrm{R}$ agonist muscimol and $\mathrm{GABA}_{\mathrm{A}} \mathrm{R}$ antagonist bicuculline, D2R antagonist L-sulpiride, PKA inhibitor H89 and PKC inhibitor GF109203X were purchased from Sigma-Aldrich, D1R agonist SKF38393 was purchased from Tocris, and PKC activator PMA, CB1R antagonist AM251 and CB1R agonist WIN55,212-2 were obtained from Medchemexpress. SKF38393, SCH23390, quinpirole, CNQX, muscimol, and bicuculline were dissolved in distilled water. L-sulpiride, H89, GF109203X and PMA, AM251 and WIN55,212-2 were dissolved in 1.0\% DMSO for stock solutions.

For the bath-application of the slices, SKF38393 $(10 \mu \mathrm{M}), \mathrm{SCH} 23390(10 \mu \mathrm{M})$, quinpirole $(10 \mu \mathrm{M})$, L-sulpiride $(20 \mu \mathrm{M})$, CNQX $(10 \mu \mathrm{M})$, muscimol $(10 \mu \mathrm{M})$, bicuculline $(10 \mu \mathrm{M})$, AM251 $(10 \mu \mathrm{M})$, and WIN55,212-2 $(10 \mu \mathrm{M})$ were diluted by ACSF to a concentration of $0.1 \%$ DMSO (Bissière et al., 2003; Dallerac et al., 2011; Soni et al., 2014; Zhang et al., 2017). For in vivo administration, SKF38393 (10 mg/kg) and quinpirole $(2 \mathrm{mg} / \mathrm{kg})$ were intraperitoneally (i.p.) injected (Zhang et al., 2016). For micro-injection of BLA, mice were anesthetized with chloral hydrate $(400 \mathrm{mg} / \mathrm{kg}$, i.p.) and were then placed into a stereotaxic instrument (Stoelting, Wood Dale, IL, United States). A small hole (2 $\mathrm{mm}$ diameter) was drilled 
in the skull using a dental drill. A guide cannula (26-gauge, Plastics One, Roanoke, VA, United States) was implanted into the BLA (1.4 mm posterior, $\pm 3.0 \mathrm{~mm}$ lateral, and $4.8 \mathrm{~mm}$ ventral to bregma). On day 3 after surgery, the dummy cannula was removed from the guide cannula, and then replaced by infusion cannulas (30 gauge) connected by polyethylene tubing (PE10; Becton Dickinson, Sparks, MD, United States) with a steppermotorized micro-syringe (Stoelting, Wood Dale, IL, United States). SKF38393 (0.1 $\mu \mathrm{g} /$ mouse), SCH23390 (0.25 $\mu \mathrm{g} / \mathrm{mouse})$, quinpirole (0.5 $\mu \mathrm{g} / \mathrm{mouse})$, L-sulpiride (0.25 $\mu \mathrm{g} / \mathrm{mouse})$, muscimol (4 nmol/mouse), H89 (2 nmol/mouse), PMA (48 pmol/mouse), and GF109203X (5 ng/side) were diluted with sterile saline and injected in a volume of $0.25 \mu \mathrm{l} /$ side BLA (Kim et al., 2000; Zeni et al., 2012; Nasehi et al., 2016). Control mice were given an equal volume of vehicle. After 2\% Evans Blue $(0.5 \mu \mathrm{l})$ was injected, the mice were killed by an overdose of chloral hydrate, and coronal sections $(100 \mu \mathrm{m})$ were cut using a cryostat to validate the injection site.

\section{Behavioral Examination Open-Field Test}

Mice were examined in a cuboid plexiglass box $(60 \mathrm{~cm} \times 60 \mathrm{~cm} \times 40 \mathrm{~cm}$ ) with the gray floor divided into 16 equal squares. The central zone was defined as the central 4 squares $(30 \mathrm{~cm} \times 30 \mathrm{~cm})$. Boxes were evenly illuminated with white light (25 lx). Each mouse was placed in a corner of the arena and allowed to freely explore for $5 \mathrm{~min}$. The following parameters were evaluated: (i) total distance traveled ( $\mathrm{mm} / 5 \mathrm{~min}$ ), calculated as the number of partitions crossed within $5 \mathrm{~min}$; and (ii) the time spent in the center region of the arena (Ping et al., 2014).

\section{Elevated Plus-Maze}

The apparatus consisted of two open arms $(23.5 \mathrm{~cm} \times 8 \mathrm{~cm})$, painted white, and two enclosed arms $(23.5 \mathrm{~cm} \times 8 \mathrm{~cm} \times 20 \mathrm{~cm}$ high), painted black. The maze was raised to a height of $38.5 \mathrm{~cm}$ above the floor. Lighting in the maze was $15 \mathrm{~lx}$. Mice were placed in the center area facing one of the open arms and their movement and time spent in the different arms were analyzed for $5 \mathrm{~min}$. The data were expressed as the time spent in the open arms (Zhang et al., 2010).

\section{Electrophysiological Analysis Field Potential Recording}

Mice (8-weeks-old) were decapitated under deep anesthesia with isoflurane. The brains were rapidly removed. The coronal slices (400 $\mu \mathrm{m})$ were cut using a vibrating microtome (Microslicer DTK 1500, Dousaka EM, Co., Kyoto, Japan) in ice-cold oxygenated $\left(95 \% \mathrm{O}_{2} / 5 \% \mathrm{CO}_{2}\right)$ cutting solution composed of (in mM) 94 sucrose, $30 \mathrm{NaCl}, 4.5 \mathrm{KCl}, 1.0 \mathrm{MgCl}_{2}, 26 \mathrm{NaHCO}_{3}, 1.2$ $\mathrm{NaH}_{2} \mathrm{PO}_{4}$, and 10 D-glucose, $\mathrm{pH}$ 7.4. After a 1-h recovery, the slices containing the cortex and amygdala were transferred to a recording chamber and continuously perfused with oxygenated ACSF composed of (in mM) $124 \mathrm{NaCl}, 2 \mathrm{CaCl}_{2}, 4.5 \mathrm{KCl}, 1$ $\mathrm{MgCl}_{2}, 26 \mathrm{NaHCO}_{3}, 1.2 \mathrm{NaH}_{2} \mathrm{PO}_{4}$, and $10 \mathrm{D}$-glucose ( $\mathrm{pH}$ value of ACSF was adjusted to 7.4) at $30 \pm 1^{\circ} \mathrm{C}$. A bipolar tungsten electrode was placed outside of the BLA to stimulate the external capsule (EC) fibers from the cortex. The constant current pulses (pulse width: $100 \mathrm{~ms}$; frequency: $0.05 \mathrm{~Hz}$ ) were supplied by a stimulator (SEN-3301, Nihon Kohden, Japan). Field excitatory post-synaptic potential (fEPSP) were recorded from the BLA with a 5-M $\Omega$ resistance glass microelectrode that was filled with $2 \mathrm{M} \mathrm{NaCl}$ and connected to a neutralized, high inputimpedance preamplifier with a high-pass filter at $5 \mathrm{kHz}$. Signals were amplified with a differential AC amplifier (A-M Systems, model 1700, Seattle, WA, United States) and were digitized using the pCLAMP system (Axon Instrument, Inc., Sunnyvale, CA, United States). The test stimulus was set at approximately $50 \%$ of the maximum stimulus intensity that evoked a saturated fEPSP slope in each slice. Paired-pulse facilitation (PPF) or inhibition (PPI) was induced by paired-pulse stimulation with interpulse interval (IPI) of 75 or $25 \mathrm{~ms}$, respectively. The pairedpulse ratio (PPR) was calculated with the following formula: $\left(\mathrm{fEPSP}_{\mathrm{S} 2} / \mathrm{fEPSP}_{\mathrm{S} 1}\right) \times 100$, where $\mathrm{fEPSP}_{\mathrm{S} 1}$ and $\mathrm{fEPSP}_{\mathrm{S} 2}$ represent the fEPSP slopes evoked by the first and second stimulation, respectively. LTP was induced using high-frequency stimulation (HFS, $100 \mathrm{~Hz}$ for $1 \mathrm{~s}$ ) consisting of five trains with $20 \mathrm{~s}$ intervals (Zhang et al., 2017). LTD was induced by low-frequency stimulation (LFS, $1 \mathrm{~Hz}$ for $15 \mathrm{~min}$ ). The degree of LTP or LTD was expressed as a percent increase or decrease comparised with the baseline of the fEPSP slopes. The 20\% greater or lower values of fEPSP slopes at 55-60 min after delivering HFS or LFS than baseline were considered as the induction of LTP or LTD.

\section{Whole Cell Patch-Clamp Recording}

Mice (4-week-old) were anesthetized with isoflurane and decapitated. The coronal section $(400 \mu \mathrm{m})$ was cut using a vibrating microtome in ice-cold ACSF (in $\mathrm{mM}$ : $\mathrm{NaCl} 126$, $\mathrm{CaCl}_{2} 1, \mathrm{KCl} 2.5, \mathrm{MgCl}_{2} 1, \mathrm{NaHCO}_{3} 26, \mathrm{KH}_{2} \mathrm{PO}_{4} 1.25$, and D-glucose 20, pH 7.4) oxygenated with 95\% $\mathrm{O}_{2} / 5 \% \mathrm{CO}_{2}$. The slices were incubated at $32-34^{\circ} \mathrm{C}$ using an in-line heating device (Warner Instruments, Hamden, CT, United States) for $60 \mathrm{~min}$, and then transferred to a recording chamber. A glass pipette (4-5 $\mathrm{M} \Omega$ resistance) was filled with an internal solution (in mM: $\mathrm{CsCl} 140, \mathrm{CaCl}_{2}$ 1, $\mathrm{MgCl}_{2}$ 2, Tris-ATP 2, HEPES 10, EGTA 10) at $\mathrm{pH}$ 7.2. The slice was perfused continually using ACSF supplemented with bicuculline $(10 \mathrm{mM})$, NBQX (10 mM), and TTX $(0.1 \mathrm{mM})$. The holding potential was $-60 \mathrm{mV}$. GABA-activated current $\left(I_{\mathrm{GABA}}\right)$ in BLA principal neurons was induced by the application of GABA (1-300 $\mu \mathrm{M})$ using a rapid drug delivery system (Hong $Z$. et al., 2016) and recorded using an EPC-10 amplifier (HEKA Elektronik, Lambrecht/Pfalz, Germany). The density of $I_{\mathrm{GABA}}$ was normalized to the maximum $I_{\mathrm{GABA}}$ recorded in the same neuron to produce a dose-response curve. The data were fitted to logistic equation in which $I=I_{\max } /[1+(\mathrm{EC} 50 / C) n]$, with $n$ being the Hill coefficient and EC50 being the concentration producing a 50\% maximal response.

\section{Western Blotting Analysis}

The coronal sections $(500 \mu \mathrm{m})$ from $-1.5 \mathrm{~mm}$ to $-2.0 \mathrm{~mm}$ relative to Bregma were cut using a cryostat microtome (CM1900, Wetzlar, Hessen, Germany) according to the mice brain atlas (Paxinos and Franklin, 2004). The region containing 
the BLA was harvested using a 15-gauge needle (inner diameter $1.5 \mathrm{~mm}$ ) and homogenized in a lysis buffer containing $50 \mathrm{mM}$ Tris- $\mathrm{HCl}$ ( $\mathrm{pH}$ 7.5), $150 \mathrm{mM} \mathrm{NaCl}, 5 \mathrm{mM}$ EDTA, $10 \mathrm{mM} \mathrm{NaF}, 1 \mathrm{mM}$ sodium orthovanadate, $1 \%$ Triton $\mathrm{X}-100,0.5 \%$ sodium deoxycholate, $1 \mathrm{mM}$ phenylmethylsulfonyl fluoride and protease inhibitor cocktail (Roche, Germany). Protein concentration was determined with the BCA Protein Assay Kit (Pierce Biotechnology, Inc., United States). Total protein (20-50 $\mu \mathrm{g}$ ) was separated by SDS-polyacrylamide gel electrophoresis and transferred to a polyphorylated difluoride membrane. The membranes were incubated with 5\% nonfat dried milk for $60 \mathrm{~min}$ and then incubated in the antibodies of anti-GABA $\mathrm{A}-\alpha 2$ (1:500, Bioworld Technology), anti-PKA phosphorylation (1:1000, Cell Signaling Technology, Inc., Boston, MA, United States), anti-PKC phosphorylation (1:1000, Abcam, Cambridge, United Kingdom). The membranes were incubated at $4^{\circ} \mathrm{C}$ overnight with HRP-labeled secondary antibodies and developed using the ECL detection Kit (Millipore, Billerica, MA, United States). Following visualization, the blots were stripped by incubation in stripping buffer (Restore; Pierce) for $15 \mathrm{~min}$; and then incubated with antibodies of anti-PKA (1:1000, Cell Signaling Technology), anti-PKC (1:1000, Abcam), anti- $\beta$-actin (1:1000, Cell Signaling Technology). BLA samples from six mice were repeated in triplicate. Western blotting bands were scanned and analyzed using the Image $J$ analysis software package (NIH). The densitometric value of phosphorylated protein normalized by total protein was normalized by the controls.

\section{Reverse Transcription-Polymerase Chain Reaction (RT-PCR)}

Total RNA was isolated from the BLA with TRIzol reagent (Invitrogen, Camarillo, CA, United States) and reversetranscribed into cDNA using a Prime Script RT reagent kit (Takara, China) for quantitative PCR (ABI Step One Plus, Foster City, CA, United States) in the presence of a fluorescent dye (SYBR Green I; Takara, China). The relative expression of genes was determined using the $2^{-\Delta \Delta c t}$ method with normalization to $G A P D H$ expression. The primer sets used for $D 1 R, D 2 R$, $G A B A_{\mathrm{A}} R-\alpha 2, G A B A_{\mathrm{A}} R-\alpha 4, G l u R 1, G l u R 2, N R 2 A$, and $N R 2 B$ were designed according to the publications (Kim et al., 2010, 2015; Zhou et al., 2016).

\section{Tyrosine Hydroxylase (TH) Immunostaining}

The mice were anesthetized with chloral hydrate $(400 \mathrm{mg} / \mathrm{kg}$, i.p.), and then perfused with $4 \%$ paraformaldehyde. The freefloating sections $(40 \mu \mathrm{m})$ were incubated with the antibody of chicken anti-TH $\left(1: 1000\right.$, Abcam) at $4^{\circ} \mathrm{C}$ overnight, and then in the antibody of biotin-labeled goat anti-chicken IgG antibody (1:500, Abcam) for $2 \mathrm{~h}$ at room temperature. Immunoreactivities were visualized using an avidin-biotin horseradish peroxidase complex (Vector Laboratories, Inc., Burlingame, CA, United States). TH-positive fibers were observed using a conventional light microscope $(40 \times$ objective, DP70; Olympus).

\section{Statistical Analysis}

The data were retrieved and processed with the software, Microcal Origin 9.1. The group data are expressed as the mean \pm standard error (SE). Experimental results were compared among treatment groups by ANOVAs followed by Bonferroni's post hoc test. Statistical analyses were performed using Stata7 software (STATA Corporation, United States). $p<0.05$ was considered statistically significant.

\section{RESULTS}

\section{MPTP-Induced Dopamine Depletion via Decrease of D2R Activation Enhances Glutamate Release in BLA}

Consistent with MPTP-induced reduction in the tyrosine hydroxylase (TH) positive cells in VTA and SNpc (Zhang et al., 2016), the density of TH positive fibers in BLA was significantly reduced by MPTP-injection for 5 days in mice (MPTP-mice) (Figure 1A). Dopamine depletion by MPTP in caudate and putamen has been reported to increase the densities D1R and D2R (Rico et al., 2017). Although the MPTP-mice had a tendency to elevate the levels of $D 1 R$ and $D 2 R$ mRNA in BLA, the group when compared with control mice failed to reach the significance $(p>0.05, n=6$ mice; Figure 1B).

By stimulating the EC fibers (Figure 1C), we recorded a fEPSP in the BLA using a field potential recording, termed "EC-BLA synaptic transmission". An input-output curve was created by plotting fEPSP slopes against stimulating intensities (SIs) from 0.2 to $0.7 \mathrm{~mA}$. As shown in Figure 1D, the fEPSP slopes $(0.4-0.6 \mathrm{~mA} / \mathrm{SI})$ in MPTP-mice were significantly increased compared to controls ( $p<0.05, n=8$ slices/ 6 mice). Either basal fEPSP slopes in control mice or the increased fEPSP slopes in MPTP-mice were abolished by the addition of $10 \mu \mathrm{M}$ AMPA receptor antagonist CNQX $(p<0.01, n=8$ slices $/ 6$ mice; Figure 1E). The PPF of fEPSP slopes was induced by delivering paired-pulse stimulation (0.5-mA/SI) with a $75 \mathrm{~ms}$ IPI to evaluate the probability of presynaptic glutamate release. The PPF value in MPTP-mice was less than that in control mice $(p<0.01, n=8$ slices $/ 6$ mice; Figure $1 \mathbf{F})$. The increased fEPSP slopes or the reduced PPF value in MPTP-mice could be corrected by the bath-application of the D2R agonist quinpirole (10 $\mu \mathrm{M}$, fEPSP slopes: $p<0.05, n=8$ slices $/ 6$ mice; PPF value: $p<0.01, n=8$ slices $/ 6$ mice) or the CB1R agonist WIN55,212-2 (10 $\mu \mathrm{M}$, fEPSP slopes: $p<0.01, n=8$ slices $/ 6$ mice; PPF value: $p<0.01, n=8$ slices $/ 6$ mice), but not the D1R agonist SKF38393 (10 $\mu \mathrm{M}, p>0.05, n=8$ slices/6 mice). The effects of quinpirole on the increased fEPSP slopes or the reduced PPF value in MPTP-mice were blocked by the co-application of CB1R antagonist AM251 (10 $\mu \mathrm{M}$ ) (fEPSP slopes: $p<0.05, n=8$ slices/ 6 mice; PPF value: $p<0.01$, $n=8$ slices $/ 6$ mice). In the slices of the control mice, the bath-application of the D2R antagonist L-sulpiride $(20 \mu \mathrm{M})$ or AM251 $(10 \mu \mathrm{M})$ caused an increase in the fEPSP slope (L-su: $p<0.05, n=8$ slices/6 mice; AM251: $p<0.05, n=8$ slices $/ 6$ mice) with a reduction of the PPF value (L-su: $p<0.01, n=8$ 

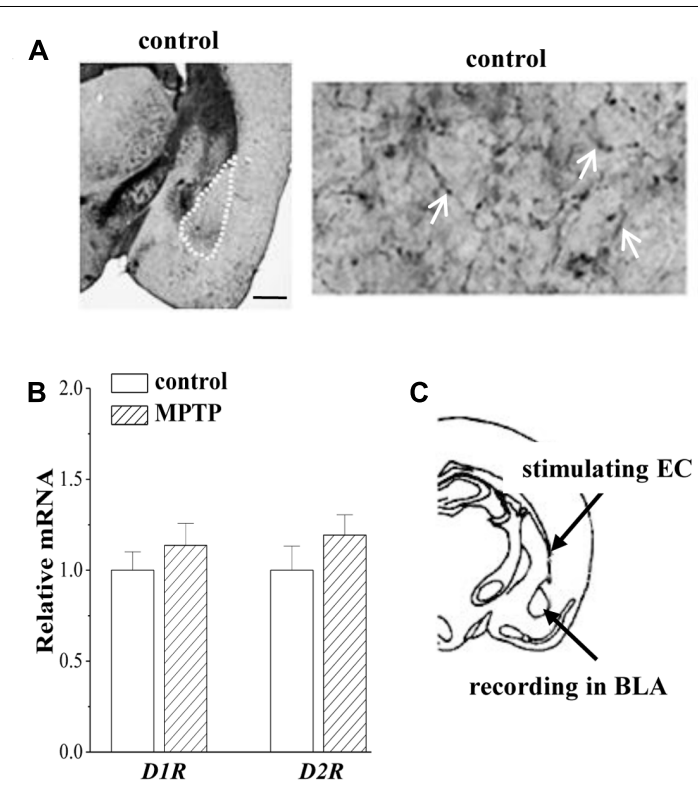

C

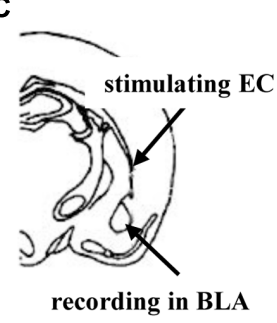

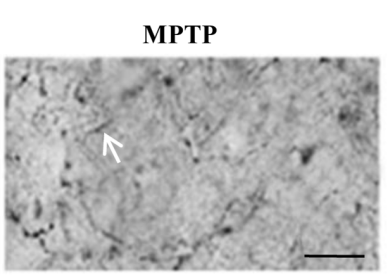

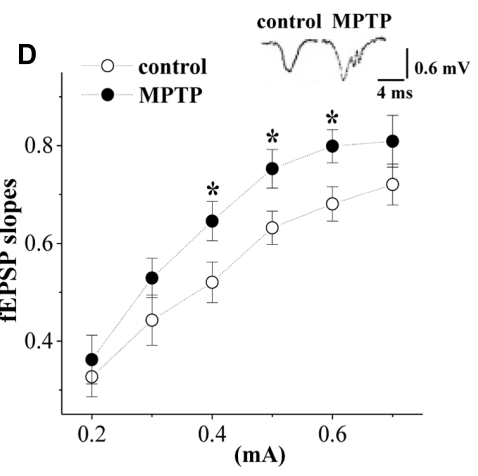

E

Bath-application of drugs

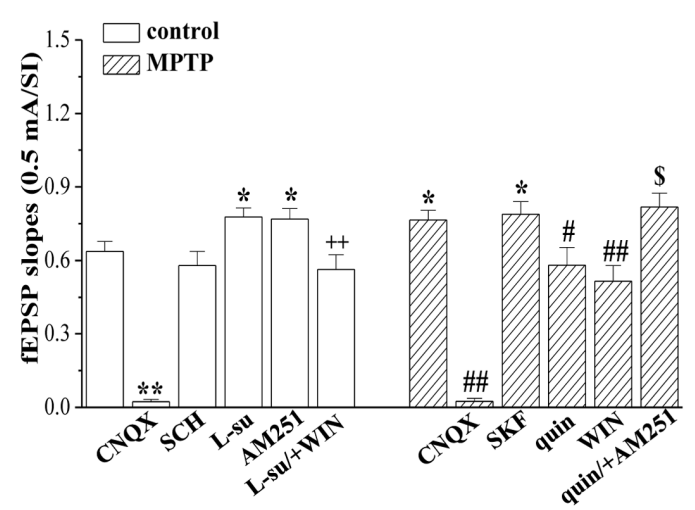

$\mathbf{F}$

Bath-application of drugs

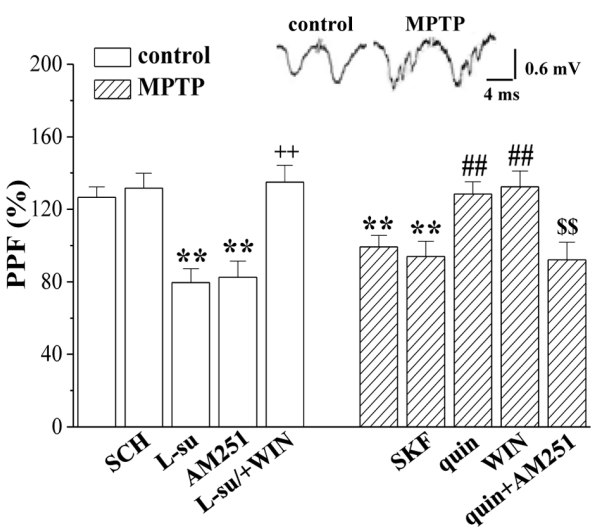

FIGURE 1 | MPTP-induced dopamine depletion enhances presynaptic glutamate release. (A) Representative photomicrograph of TH-immunohistochemical staining in control mice (control) and MPTP-mice (MPTP). The BLA area is indicated by a white broken line (left panel). Scale bars $=1 \mathrm{~mm}$. The arrows indicate TH positive fibers in BLA at high magnification. Scale bars $=50 \mu \mathrm{m}$. (B) Bar graphs show levels of D1R and D2R mRNA in BLA of control mice and MPTP-mice. (C) Schematic illustrating the locations of stimulating external capsule (EC) fibers and field potential recording in BLA. (D) Input-output (I/O) curve in BLA. Each point represents the group mean of the fEPSP slopes against stimulating intensities (SIs) from 0.2 to $0.7 \mathrm{~mA}$. Two-way ANOVA, MPTP: $F_{(1,84)}=15.393, p<0.001 ;$ SI: $F_{(5,84)}=29.953$, $p<0.001 ;$ MPTP $\times$ SI: $F_{(5,84)}=0.325, p<0.001 .{ }^{*} p<0.05$ vs. control mice. (E,F) Bar graphs show the mean of fEPSP slopes $(0.5 \mathrm{~mA} / \mathrm{SI})$ or PPF $(75 \mathrm{~ms}$ IPI, \%) in the slices of control mice treated with D1R antagonist SCH23390 (SCH), D2R antagonist L-sulpiride (L-Su), CB1R antagonist AM251, AMPA receptor antagonist CNQX, or the co-application of L-sulpiride and CB1R agonist WIN55,212-2 (L-su/+WIN); in the slices of MPTP-mice treated with D1R agonist SKF38393 (SKF), D2R agonist quinpirole (quin), CB1R agonist WIN55,212-2 (WIN), AMPA receptor antagonist CNQX or the co-application of quinpirole and AM251 (quin/+AM251). ${ }^{*} p<0.05$ and ${ }^{* *} p<0.01$ vs. control mice; $++p<0.01$ vs. control mice treated with L-su; ${ }^{\#} p<0.05$ and ${ }^{\# \#} p<0.01$ vs. MPTP-mice; ${ }^{\$} p<0.05$ and ${ }^{\$ \$} p<0.01$ vs. MPTP-mice treated with quin.

slices/6 mice; AM251: $p<0.01, n=8$ slices/6 mice), whereas the D1R antagonist SCH23390 $(10 \mu \mathrm{M})$ did not $(p>0.05$, $n=8$ slices $/ 6$ mice). The effects of L-sulpiride on the fEPSP slope and the PPF value were sensitive to the co-application of WIN55,212-2 (fEPSP slopes: $p<0.01, n=8$ slices/ 6 mice; PPF value: $p<0.01, n=8$ slices $/ 6$ mice). The results indicate that the activation of D2R inhibits the glutamate release from EC fibers in a CB1R-dependent manner; the MPTP-induced dopamine depletion through reducing D2R and CB1R activation enhances the glutamate release.

\section{MPTP-Induced Dopamine Depletion Attenuates GABAergic Neurotransmission in BLA}

A large body of evidence has established that abundant GABAergic local circuits in BLA build an excitation-inhibition 


\section{A}

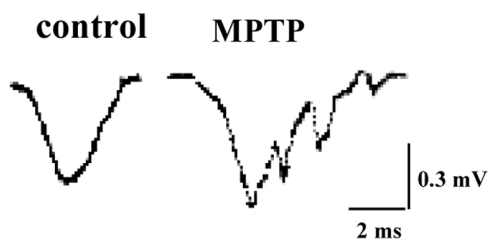

C

\section{Bath-application of drugs}

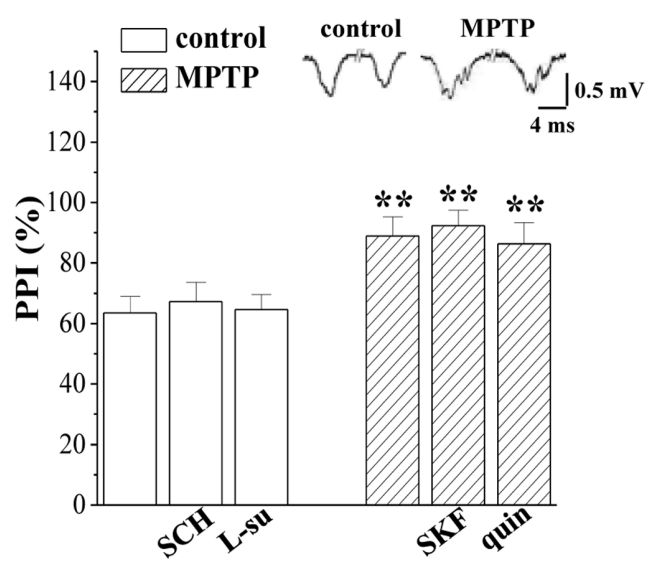

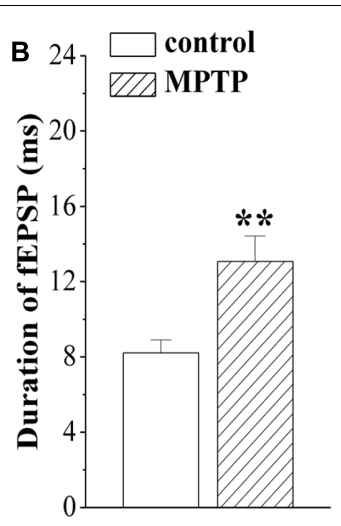

D

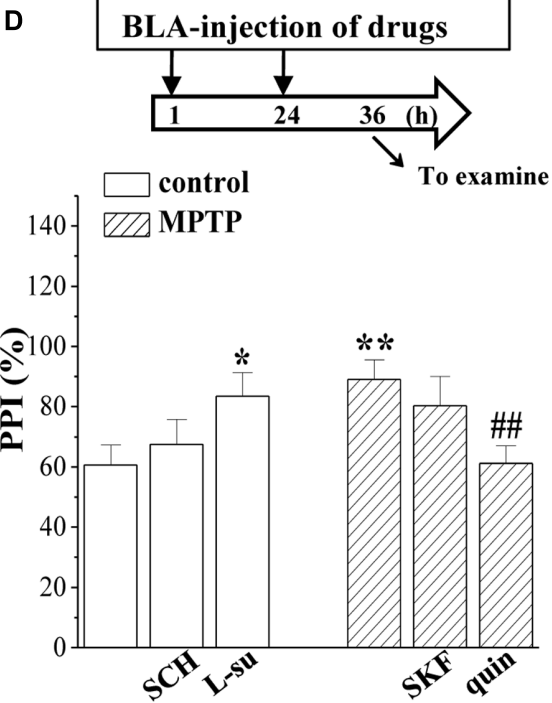

FIGURE 2 | MPTP-induced dopamine depletion attenuates GABAergic neurotransmission. (A) Representative traces of fEPSP evoked by 0.5 mA/SI in control mice (control) and MPTP-mice (MPTP). (B) Bar graphs show the mean duration (ms) of fEPSP in control mice and MPTP-mice. ** $p<0.01$ vs. control mice. (C,D) Bar graphs show the PPI (25 ms IPI, \%) in the slices of control mice treated with SCH23390 (SCH) or L-sulpiride (L-su) for 20 min; in the slices of MPTP-mice treated with SKF38393 (SKF) or quinpirole (quin); in control mice treated with BLA-injection of SCH23390 (SCH) or L-sulpiride (L-su) for 2 days; in MPTP-mice treated with BLA-injection of SKF38393 (SKF) or quinpirole (quin). (D) Time chart of the experimental procedure (upper panel). $\downarrow$ : time of drug administration; $\searrow$ : time of electrophysiological experiments. ${ }^{*} p<0.05$ and ${ }^{* *} p<0.01$ vs. control mice; ${ }^{\# \#} p<0.01$ vs. MPTP-mice (two-way ANOVA).

cycle (Isoardi et al., 2004). The GABAergic inhibition is reduced in the dopamine-depleted animals (Janssen et al., 2016). Compared with the single waveform fEPSP in control mice, the same stimulation elicited a multi-spike waveform fEPSP in the BLA of MPTP-mice (Figure 2A). Additionally, the fEPSP duration in MPTP-mice was longer than that in control mice ( $p<0.01, n=8$ slices $/ 6$ mice; Figure 2B). The PPI is considered to depend on GABAergic inhibitory circuit in BLA (Delaney and Sah, 2001). Notably, the PPI of fEPSP slopes induced by delivering paired-pulse stimulation (0.5 mA/SI) with $25 \mathrm{~ms}$ IPI in MPTP-mice was increased compared to that of the control mice $(p<0.01, n=8$ slices/6 mice; Figure 2C). The increased PPI value in MPTPmice was insensitive to the bath-application of quinpirole or SKF38393 ( $p>0.05, n=8$ slices/6 mice). However, the BLA-injection of quinpirole $(0.5 \mu \mathrm{g} /$ mouse $)$ for continuous 2 days (Figure 2D) corrected the increased PPI value $(p<0.01$, $n=8$ slices $/ 6$ mice $)$, but SKF38393 ( $0.1 \mu \mathrm{g} /$ mouse $)$ had no effects ( $p>0.05, n=8$ slices/ 6 mice). The BLA-injection of L-sulpiride (0.25 $\mu \mathrm{g} /$ mouse) for 2 days increased the PPI value in control mice $(p<0.05, n=8$ slices $/ 6$ mice), whereas the administration of SCH23390 (0.25 $\mu \mathrm{g} /$ mouse $)$ could not $(p>0.05, n=8$ slices $/ 6$ mice).

\section{MPTP-Induced Dopamine Depletion Causes GABA $_{A}$ R Down-Regulation in BLA}

GABA can exert shunting effects on excitatory transmission mainly via $\mathrm{GABA}_{\mathrm{A}} \mathrm{R}$ (Nishiyama et al., 2010). Further experiments were designed to examine the $\mathrm{GABA}_{\mathrm{A}} \mathrm{R}$ activity in BLA principal neurons using a whole cell patch-clamp recording. Local perfusion with the $\mathrm{GABA}_{\mathrm{A}} \mathrm{R}$ agonist GABA $(10 \mu \mathrm{M})$ evoked an inward currents $\left(I_{\mathrm{GABA}}\right)$ (Figure $3 \mathrm{~A}$ ), which was 


\section{A}

GABA-evoked currents $\left(I_{\mathrm{GABA}}\right)$<smiles>CCC1CCCC1[Ge]</smiles>

bicu

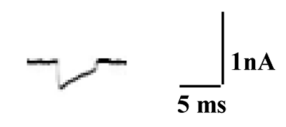

C

Bath-application of drugs

-O- control

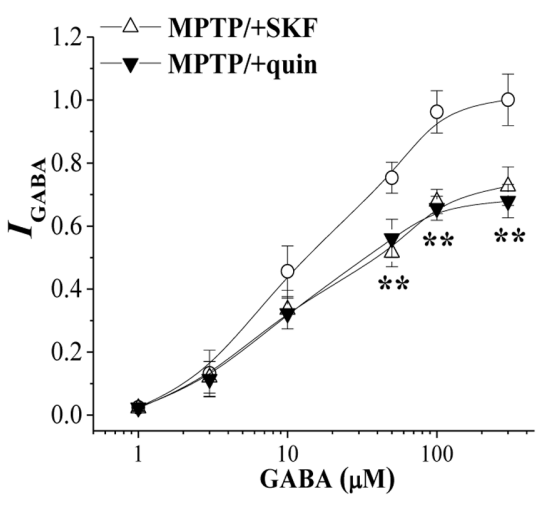

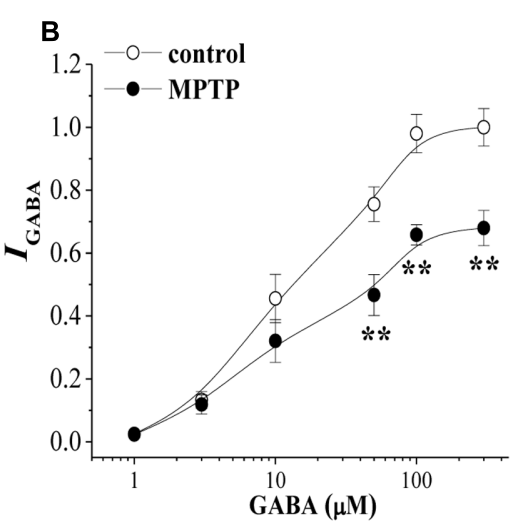

D Injection (i.p.) of drugs

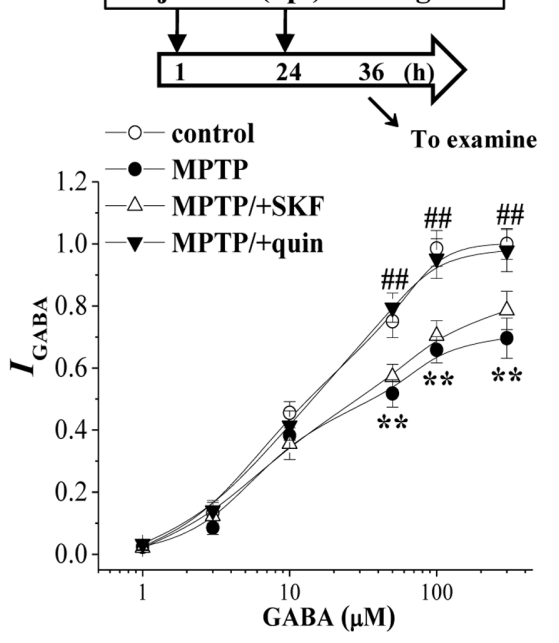

FIGURE 3 | MPTP-induced dopamine depletion causes GABA $R$ dysfunction. (A) Representative traces of whole cell currents evoked by $10 \mu \mathrm{M}$ GABA ( ${ }_{\text {GABA }}$ ) in control slices or the slices treated with bicuculline (bicu). (B) The densities of IGABA evoked by GABA (1-300 $\mu$ M) in control mice and MPTP-mice. Each point represents the density of $I_{\text {GABA }}$ normalized by a control value evoked by GABA $(10 \mu \mathrm{M})$. Repeated-measure ANOVA, $F_{(1,14)}=37.32, p<0.001$. $* * p<0.01$ vs. control mice. (C) Evoked IGABA by GABA (1-300 $\mu \mathrm{M})$ in slices of MPTP-mice treated with SKF38393 (SKF) or quinpirole (quin). ${ }^{* *} p<0.01$ vs. control mice. (D) Evoked I GABA by GABA (1-300 $\mu \mathrm{M}$ ) in MPTP-mice treated with the injection (i.p.) of SKF38393 (SKF) or quinpirole (quin). Time chart of the experimental procedure (upper panel). $\downarrow$ : time of drug administration; \: time of electrophysiological experiments. Repeated-measure ANOVA, MPTP: $F(1,14)=28.372$, $p<0.001$; SKF: $F_{(1,14)}=1.094, p=0.313$; quin: $F_{(1,14)}=32.941, p<0.001 .{ }^{* *} p<0.01$ vs. control mice; ${ }^{\# \#} p<0.01$ vs. MPTP-mice.

largely blocked by the $\mathrm{GABA}_{\mathrm{A}} \mathrm{R}$ antagonist bicuculline $(10 \mu \mathrm{M}$, $p<0.01, n=5$ cells $/ 4$ mice). With repeated applications of GABA in 5 min interval, the densities of $I_{\mathrm{GABA}}$ remained stable and exhibited no rundown for over $30 \mathrm{~min}$ (data not shown). The densities of $I_{\mathrm{GABA}}$ in MPTP-mice were less than those in control mice $\left(F_{1,14}=37.315, p<0.001\right.$; Figure $3 \mathrm{~B})$. The EC50 value of the dose-response curve of $I_{\mathrm{GABA}}$ had no difference between MPTP mice $(13.33 \pm 1.07 \mu \mathrm{M})$ and control mice $(12.57 \pm 1.52 \mu \mathrm{M} ; p>0.05)$. The bathapplication of SKF38393 or quinpirole failed to alter the densities of $I_{\mathrm{GABA}}$ in MPTP-mice $(p>0.05, n=8$ cells $/ 6$ mice; Figure 3C). However, the injection (i.p.) of quinpirole $(2 \mathrm{mg} / \mathrm{kg}$ ) for 2 days (Figure 3D) could correct the reduced $I_{\mathrm{GABA}}$ in MPTP-mice ( $p<0.01, n=8$ cells $/ 6$ mice), but SKF38393 $(10 \mathrm{mg} / \mathrm{kg})$ did not $(p>0.05, n=8$ cells $/ 6$ mice).

\section{MPTP-Induced Dopamine Depletion Suppresses GABA $_{A} R-\alpha 2$ Expression}

The GABAergic interneuron expresses primarily $\alpha$ subunitcontaining $\mathrm{GABA}_{\mathrm{A}} \mathrm{R}$ (McDonald and Mascagni, 2004). BLA principal neurons contain primarily the $\alpha 2$ subunit (Marowsky et al., 2004); thus, we measured the $\mathrm{GABA}_{\mathrm{A}} \mathrm{R}-\alpha 2$ and $\mathrm{GABA}_{\mathrm{A}} \mathrm{R}-\alpha 4$ expression in BLA by RT-PCR and Western blotting, respectively. The level of $G A B A_{\mathrm{A}} R-\alpha 2 \mathrm{mRNA}$ in MPTP-mice was significantly reduced compared to that in control mice ( $p<0.01, n=6$ mice; Figure 4A), but the levels of $G A B A_{\mathrm{A}} R-\alpha 4 \mathrm{mRNA}$ had no significant difference between control mice and MPTP-mice ( $p>0.05, n=6$ mice; Figure 4B). The level of $\mathrm{GABA}_{\mathrm{A}} \mathrm{R}-\alpha 2$ protein in MPTP-mice was lower than that in control mice ( $p<0.01, n=6$ mice; Figure 4C). The BLA-injection of quinpirole for continuous 2 days corrected the decreases in the levels of $G A B A_{\mathrm{A}} R-\alpha 2$ mRNA $(p<0.01$, 

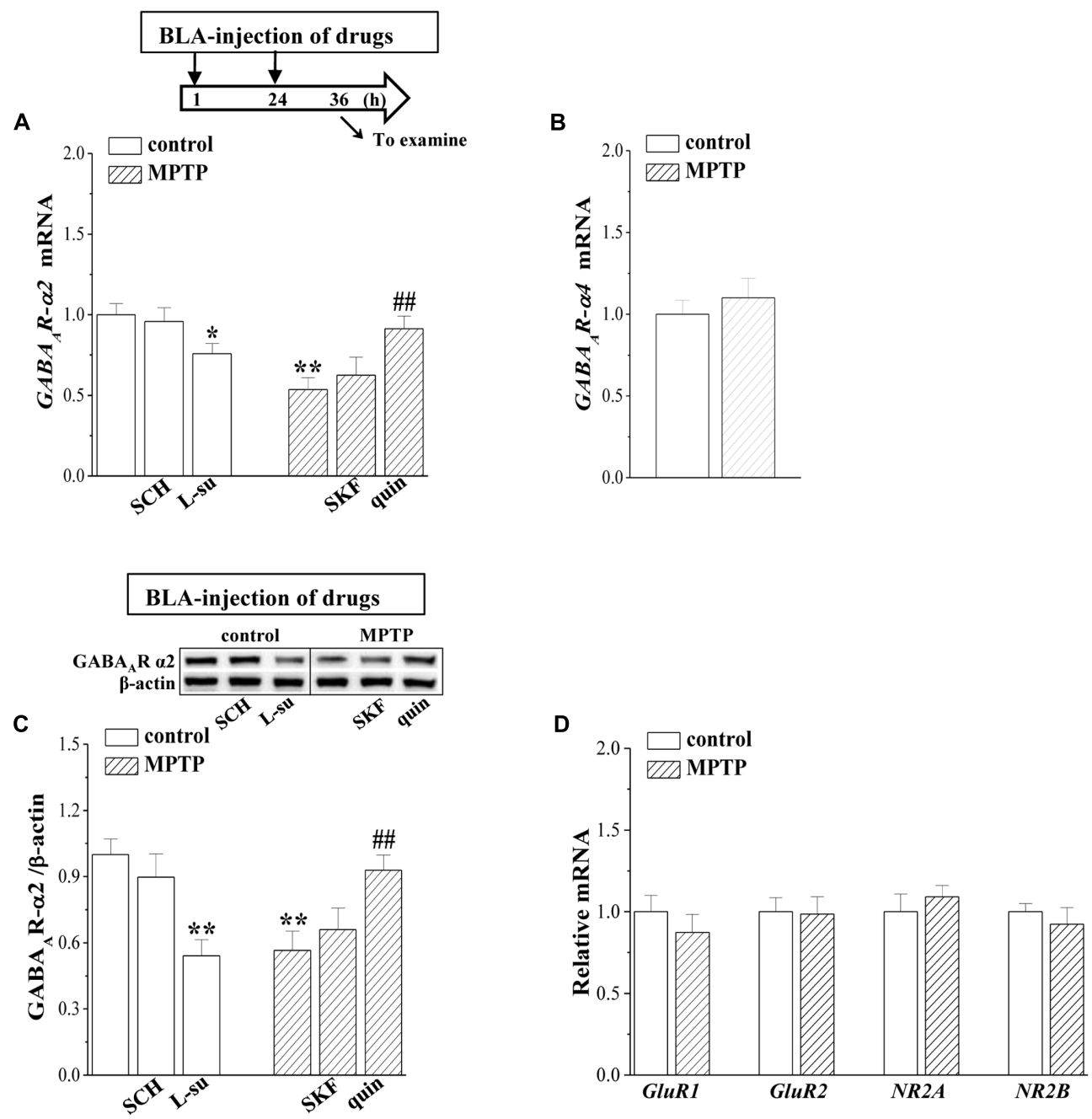

FIGURE 4 | MPTP-induced dopamine depletion suppresses GABA $A_{A} R$ expression. (A-C) Bar graphs show levels of GABA $A$ - $\alpha 2$ and $G A B A_{A} R$ - $\alpha 4$ mRNA or $\mathrm{GABA}_{A} \mathrm{R}$ - $\alpha 2$ protein in BLA of control mice treated with BLA-injection of SCH23390 (SCH) or L-sulpiride (L-Su); in MPTP-mice treated with BLA-injection of SKF38393 (SKF) or quinpirole (quin). Densitometric values of proteins normalized by the level of $\beta$-actin were normalized by control levels. (A) Time chart of the experimental procedure (upper panel). $\downarrow$ : time of drug administration; \: time of RT-PCR and Western blotting. ${ }^{*} p<0.05$ and ${ }^{* *} p<0.01$ vs. control mice; $\# \#$ < 0.01 vs. MPTP-mice (two-way ANOVA). (D) The levels of GluR1, GluR2, NR2A, NR2B mRNA in BLA of control mice and MPTP-mice.

$n=6$ mice) and protein ( $p<0.01, n=6$ mice), but SKF38393 could not $(p>0.05, n=6$ mice). In control mice, the blockade of D2R by L-sulpiride caused a decrease in the $G A B A_{\mathrm{A}} R-\alpha 2$ mRNA $(p<0.05, n=6$ mice) and protein $(p<0.01, n=6$ mice), whereas the D1R antagonist SCH23390 failed to affect the levels of $\mathrm{GABA}_{\mathrm{A}} \mathrm{R}-\alpha 2$ expression ( $p>0.05, n=6$ mice). In contrast, the levels of AMPA receptor (GluR1 and GluR2 mRNA) or NMDA receptor ( $N R 2 A$ and $N R 2 B$ mRNA) expression in MPTP-mice did not significantly differ from those of control mice $(p>0.05, n=6$ mice; Figure 4D).

\section{MPTP-Reduced D2R-Mediated PKC Activity Suppresses GABA $R$ Expression}

D2R activation can decrease the phosphorylation of PKA (phospho-PKA; Yamaguchi et al., 2015), whereas it increases the PKC phosphorylation (phospho-PKC; Hong S.I. et al., 2016). The level of phospho-PKA in control mice was elevated by the bathapplication of L-sulpiride for $20 \mathrm{~min}(p<0.01, n=6$ mice; Figure 5A) and was reduced by SCH23390 ( $p<0.05, n=6$ mice). The level of phospho-PKA in MPTP-mice was lower than that in control mice $(p<0.05, n=6$ mice), which was rescued by SKF38393 ( $p<0.01, n=6$ mice) rather than quinpirole $(p>0.05, n=6$ mice). In comparison with control mice, the level of phospho-PKC was reduced in MPTP-mice $(p<0.01$, $n=6$ mice; Figure 5B), which was corrected by the bathapplication of quinpirole ( $p<0.05, n=6$ mice) but not SKF38393 $(p>0.05, n=6$ mice). The application of L-sulpiride decreased the phospho-PKC in control mice ( $p<0.05, n=6$ mice), whereas SKF38393 failed to alter the level of phospho-PKC $(p>0.05$, $n=6$ mice). The levels of PKA and PKC proteins exhibited no significant difference between control mice and MPTP-mice $(p>0.05, n=6$ mice $)$. 


\section{A}
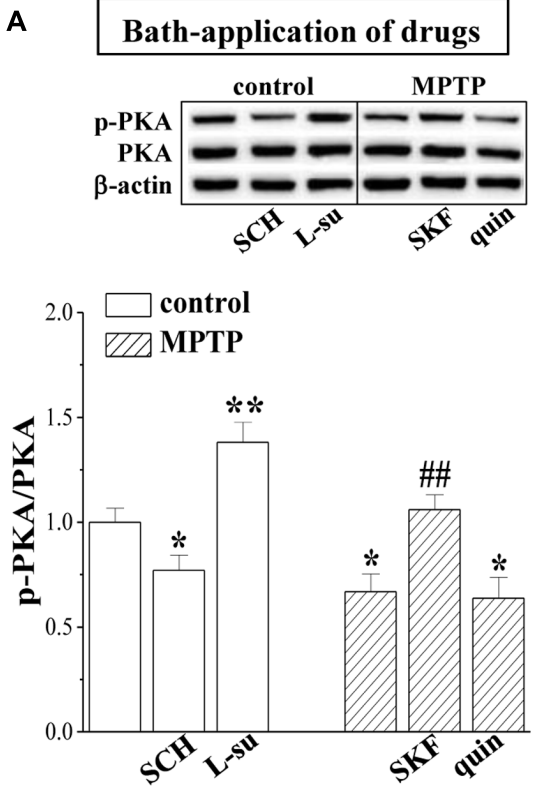

C

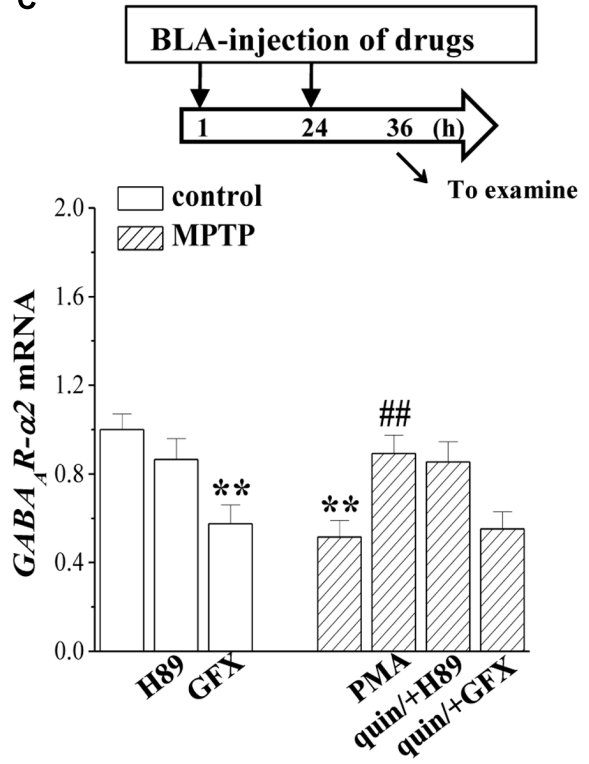

B

Bath-application of drugs
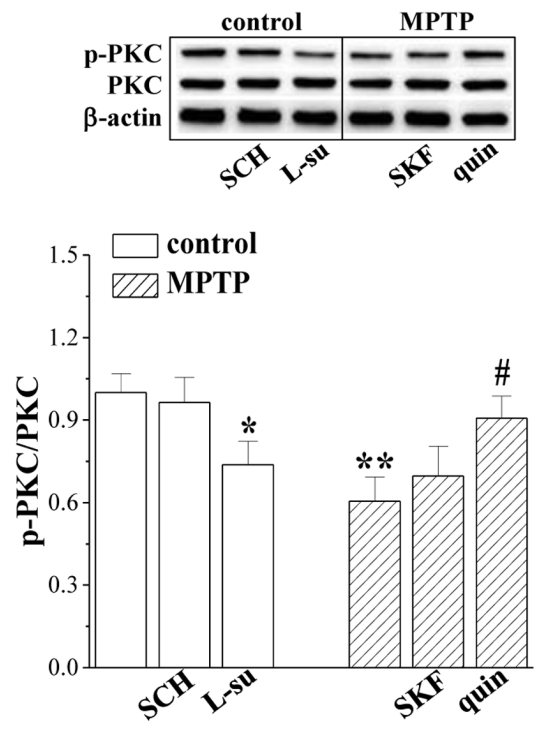

D

BLA-injection of drugs

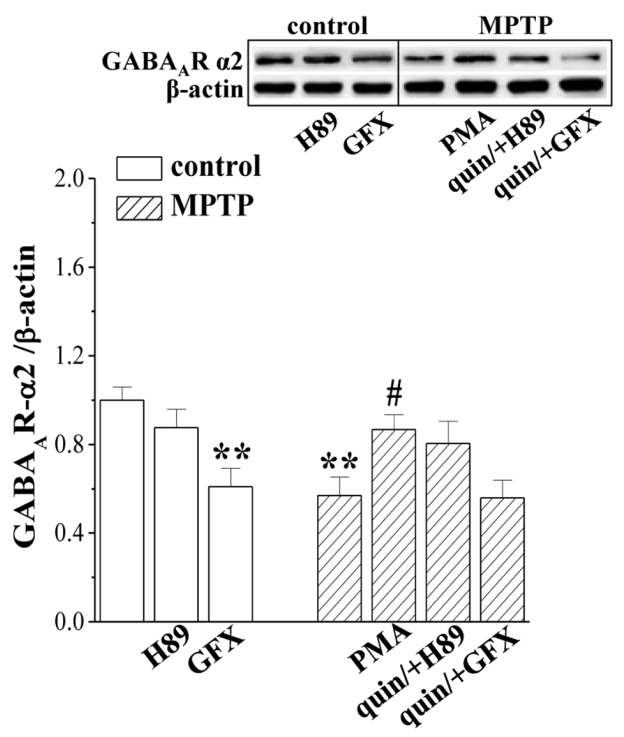

FIGURE 5 | MPTP-reduced PKC signaling suppresses GABA $A$ R expression. (A,B) Representative blots of phospho-PKA and phospho-PKC in BLA of control mice treated with bath-application of SCH23390 (SCH) or L-sulpiride (L-Su) and in MPTP-mice treated with bath-application of SKF38393 (SKF) or quinpirole (quin). Densitometric values of phospho-PKA and phospho-PKC normalized by the PKA and PKC protein were normalized by control levels. ${ }^{*} p<0.05$ and $*^{* *} p<0.01$ vs. control mice; ${ }^{\#} p<0.05$ and $\# \#<0.01$ vs. MPTP-mice (two-way ANOVA). (C,D) Bar graphs show levels of GABA ${ }_{A} R-\alpha 2$ mRNA and GABA $R$ R- $\alpha 2$ protein in BLA of control mice treated with BLA-injection of H89 or GF109203X (GFX); in MPTP-mice treated with BLA-injection of PMA, or the co-administration of quinpirole and H89 (quin/+H89) or GF109203X (quin/+GFX). (C) Time chart of the experimental procedure (upper panel). $\downarrow$ : time of drug administration; \: time of RT-PCR and Western blotting. ${ }^{*} p<0.05$ and ${ }^{* *} p<0.01$ vs. control mice; ${ }^{*} p<0.05$ and ${ }^{\# \#} p<0.01$ vs. MPTP-mice (two-way ANOVA).

The PKA activation negatively regulated the $G_{A B A} R$ expression, while the PKC activation enhanced $\mathrm{GABA}_{\mathrm{A}} \mathrm{R}$ expression (Bohnsack et al., 2016). In control mice, the
BLA-injection of the PKC inhibitor GF109203X reduced the levels of $G A B A_{\mathrm{A}} R-\alpha 2$ mRNA ( $p<0.01, n=6$ mice; Figure 5C) and protein $(p<0.01, n=6$ mice; Figure 5D). The BLA-injection 
of the PKC activator PMA in MPTP-mice corrected the decreases in the levels of $G A B A_{\mathrm{A}} R-\alpha 2$ mRNA $(p<0.01, n=6$ mice $)$ and protein $(p<0.05, n=6$ mice). Furthermore, the BLAinjection of GF109203X could prevent the quinpirole-corrected $\mathrm{GABA}_{\mathrm{A}} \mathrm{R}$ expression in MPTP-mice ( $p<0.01, n=6$ mice). By contrast, the PKA inhibitor $\mathrm{H} 89$ did not cause changes in the level of $\mathrm{GABA}_{\mathrm{A}} \mathrm{R}-\alpha 2$ expression in control mice $(p>0.05, n=6$ mice).

\section{MPTP-Reduced GABA $A_{A}$ Activity Impairs LTD Induction}

GABAergic disinhibition has been reported to affect synaptic plasticity in BLA (Rodriguez Manzanares et al., 2005). To test this possibility, we further examined the frequency-dependent LTP and LTD induction at EC-BLA synaptic transmission in control mice and MPTP-mice ( $n=6$ slices $/ 6$ mice). By delivering high-frequency $(100 \mathrm{~Hz})$ stimulation (HFS) in control mice, the fEPSP slopes were increased by approximately $40 \%$ for over $60 \mathrm{~min}$ (Figure 6A), indicative of LTP induction. A decrease in the amplitude of LTP was observed in MPTP mice compared to control mice ( $p<0.05, n=6$ slices $/ 6$ mice; at $55-60 \mathrm{~min}$ after HFS), which could be recovered by the bath-application of quinpirole ( $p<0.05, n=6$ slices $/ 6$ mice) rather than SKF38393 ( $p>0.05, n=6$ slices/6 mice; Figure 6B). Additionally, the fEPSP slopes were reduced by low-frequency $(1 \mathrm{~Hz})$ stimulation (LFS) at 900 pulses in control mice $(n=6$ slices $/ 6$ mice; Figure 6C), indicative of LTD induction, which was blocked by the $\mathrm{GABA}_{\mathrm{A}} \mathrm{R}$ antagonist bicuculline ( $n=6$ slices $/ 6$ mice). The same LFS protocol could not induce the production of LTD in MPTP-mice ( $n=6$ slices/ 6 mice; Figure 6D). The bath-application of the $\mathrm{GABA}_{\mathrm{A}} \mathrm{R}$ agonist muscimol recovered the LTD induction in MPTP-mice. Additionally, the BLAinjection of quinpirole or PMA for 2 days (Figure 6E) in MPTP-mice could rescue the LTD induction $(n=6$ slices $/ 6$ mice). In contrast, the bath-application of quinpirole failed to recover the LTD induction in MPTP-mice $(n=6$ slices/ 6 mice; Figure 6F).

\section{Involvement of MPTP-Impaired LTD Induction in Affective Disorder}

To explore the relation of the altered EC-BLA synaptic LTP and LTD to anxiety-like behaviors, an open-field test (OFT) and elevated plus-maze (EPM) were conducted on days 3-4 after administration of MPTP and drugs (Figure 7A). The distance traveled in the OFT did not differ between control mice and MPTP-mice ( $p>0.05, n=12$ mice; Figure 7B), but MPTP-mice spent less time in the central partition of the arena than control mice ( $p<0.01, n=12$ mice; Figure 7C). Additionally, the time in the open arms of the EPM was reduced in MPTP-mice compared to control mice ( $p<0.01, n=12$ mice; Figure 7D). The BLAinjection of muscimol ( $p<0.05, n=12$ mice), quinpirole ( $p<0.01, n=12$ mice) or PMA ( $p<0.05, n=12$ mice) in MPTPmice could correct the time spent in the central partition of OFT and open arms of EPM, but SKF38393 did not $(p>0.05, n=12$ mice).

\section{DISCUSSION}

Using field potential recording and patch-clamp recording, and by combined pharmacological experiments, our results indicate that the MPTP-induced dopamine depletion in BLA through reducing $\mathrm{D} 2 \mathrm{R}$ activation enhanced the presynaptic glutamate release at the EC-BLA synaptic transmission and decreased the LTP amplitude; the MPTP-induced dopamine depletion via the decrease of $\mathrm{D} 2 \mathrm{R}$ activation suppressed the expression and function of $\mathrm{GABA}_{\mathrm{A}} \mathrm{R}$ in the BLA principal neurons to reduce $G_{A B A}$ R-mediated inhibition, which impaired the LTD induction, leading to the production of anxiety-like behaviors (Figure 8).

A principal observation in this study is that the densities of $I_{\mathrm{GABA}}$ were reduced in BLA principal neurons of MPTPmice. The activation of $\mathrm{D} 1 \mathrm{R}$ has been reported to enhance the $\mathrm{GABA}_{\mathrm{A}} \mathrm{R}$ mediated IPSCs, whereas the activation of $\mathrm{D} 2 \mathrm{R}$ depresses $\mathrm{GABA}_{\mathrm{A}} \mathrm{R}$ activity (Trantham-Davidson et al., 2004). Li et al. (2011) reported that $D 2 R$ activation facilitates $G_{A B A} R$ insertion at newly formed inhibitory synapses. However, the decreased density of $I_{\mathrm{GABA}}$ in MPTP-mice failed to be altered by the bath-application of D2R or D1R agonist. By contrast, the administration of the D2R agonist for 2 days in MPTP mice was able to correct the decreased $I_{\mathrm{GABA}}$ density. Consistently, the level of $\mathrm{GABA}_{\mathrm{A}} \mathrm{R}-\alpha 2$ expression in BLA was significantly reduced in MPTP mice, which could be rescued by the D2R agonist. In mice lacking D2R, the GABAergic neurotransmission is reduced although the level of glutamic acid decarboxylase (GAD) is strongly increased (An et al., 2004). Chronic D2R stimulation has been reported to increase the density of postsynaptic $\mathrm{GABA}_{\mathrm{A}} \mathrm{R}$ clusters (Lalchandani et al., 2013). Therefore, it is highly likely that the MPTP-induced dopamine depletion via the decrease of $\mathrm{D} 2 \mathrm{R}$ activation in the BLA principal neurons suppresses $\mathrm{GABA}_{\mathrm{A}} \mathrm{R}$ expression leading to the dysfunction of $\mathrm{GABA}_{\mathrm{A}} \mathrm{R}$.

The levels of phospho-PKA and phospho-PKC in the BLA of MPTP mice were lower than those in control mice. The D1R agonist could recover the level of phospho-PKA in MPTP mice, and the D1R antagonist caused the decline of phosphoPKA in control mice. In MPTP mice, the decreased phosphoPKC was rescued by the activation of D2R rather than D1R. In control mice, the blockade of D2R inhibited the phospho-PKC and elevated the phospho-PKA. The PKC activation increases $\mathrm{GABA}_{\mathrm{A}} \mathrm{R}-\alpha 4$ expression, while the PKA activation decreases synaptic $\mathrm{GABA}_{\mathrm{A}} \mathrm{R}-\alpha 4$ expression (Bohnsack et al., 2016). PKC activation can phosphorylate the $\mathrm{GABA}_{\mathrm{A}} \mathrm{R}$ subunits at $\alpha 4$ S443 (Nakamura et al., 2015) to increase surface expression of $\mathrm{GABA}_{\mathrm{A}} \mathrm{R}-\alpha 4$ (Abramian et al., 2010; Werner et al., 2011). The activation of $D 2 R$ selectively up-regulates the $G A B A_{A} R$ expression probably via PKA signaling (Pan et al., 2008). However, the level of $\mathrm{GABA}_{\mathrm{A}} \mathrm{R}-\alpha 4$ expression in MPTP mice did not differ significantly from control mice. The BLA principal neurons primarily express the $\alpha 2$ subunit (Marowsky et al., 2004). Interestingly, the decreases in the $G A B A_{\mathrm{A}} R-\alpha 2 \mathrm{mRNA}$ and protein in MPTP mice were corrected by the PKC activator. The inhibition of PKC rather than PKA reduced the $\mathrm{GABA}_{\mathrm{A}} \mathrm{R}-\alpha 2$ expression in control mice. Moreover, the $\mathrm{PKC}$ inhibitor 


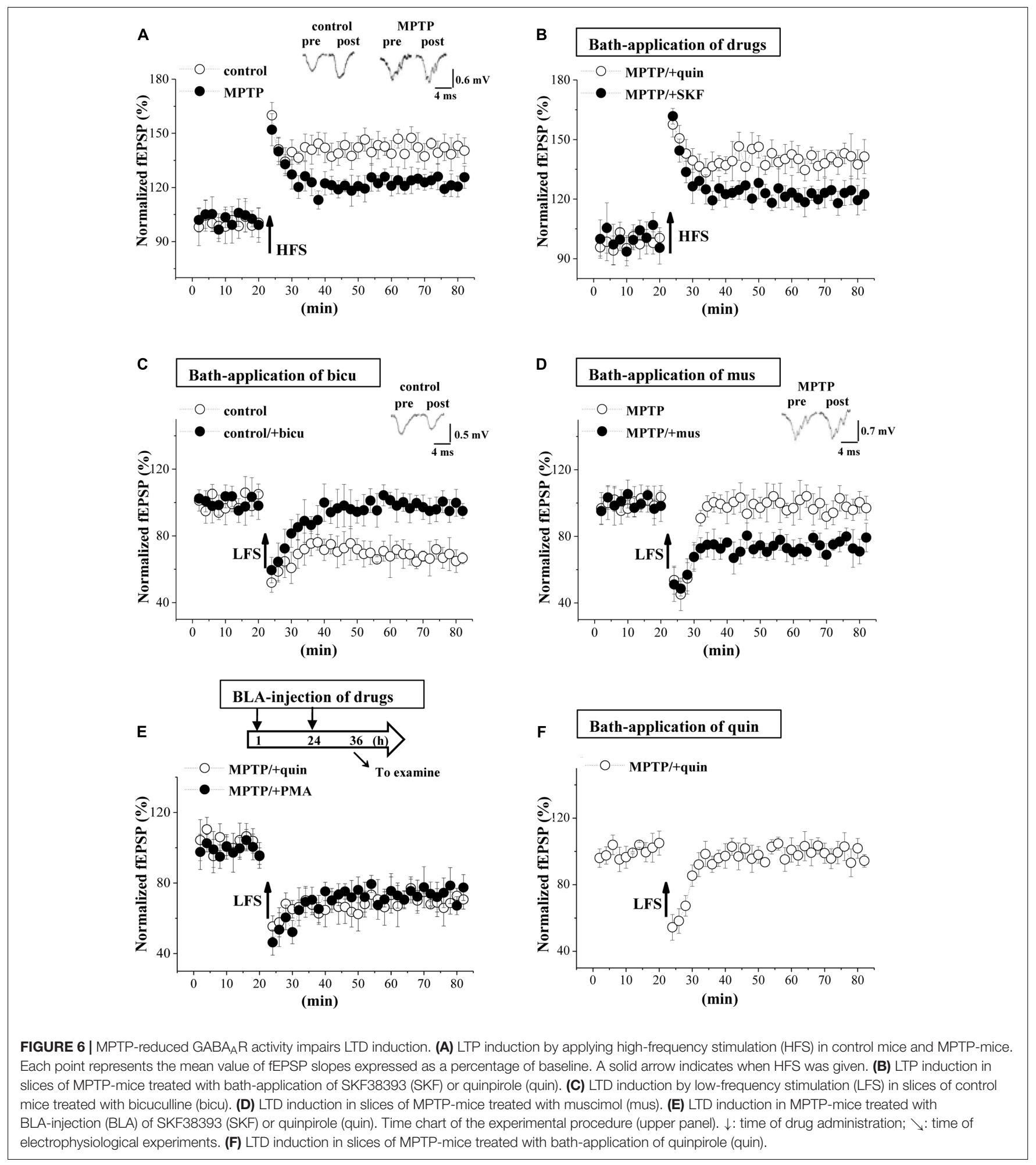

abolished the protective effects of D2R agonist on MPTPsuppressed $\mathrm{GABA}_{\mathrm{A}} \mathrm{R}-\alpha 2$ expression, but the PKA inhibitor did not. The results give an indication that the MPTP-induced dopamine depletion via the down-regulation of D2R-mediated PKC signaling suppresses $\mathrm{GABA}_{\mathrm{A}} \mathrm{R}-\alpha 2$ expression.
The MPTP-induced dopamine depletion destructed the balance between excitatory and inhibitory circuits in BLA. Flores-Hernandez et al. (1997) reported that the transmission of EC-BLA glutamatergic synapses is potentiated by activation of $\mathrm{D} 1 \mathrm{R}$ or inhibition of D2R. In the slices obtained from control 
A

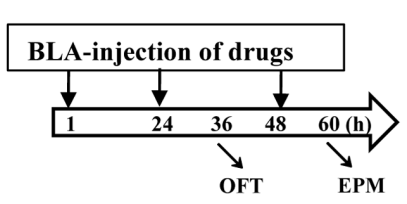

B

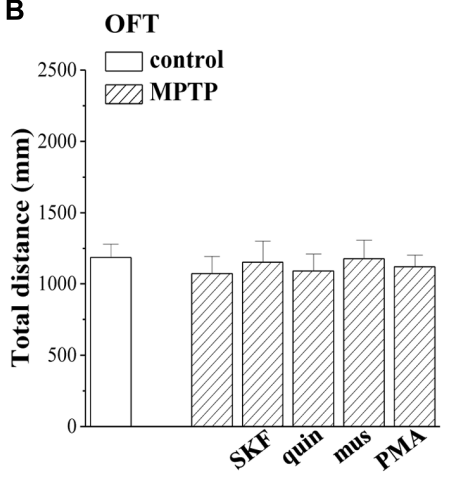

C OFT

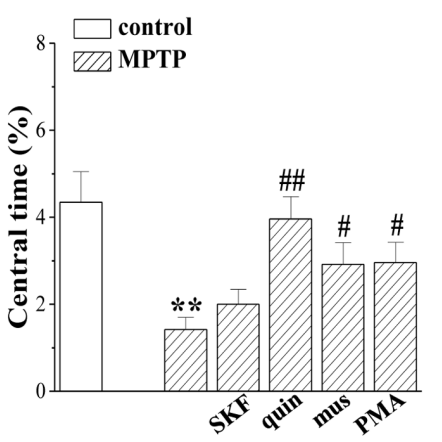

D

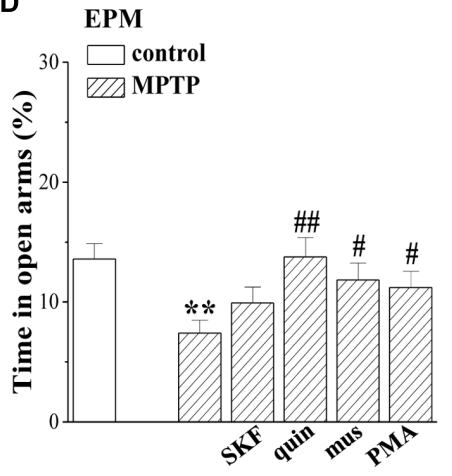

FIGURE 7 | Involvement of MPTP- impaired LTD induction in affective disorder. (A) Time chart of the experimental procedure. $\downarrow$ : time of drug administration; $\searrow$ : time of OFT and EPM, respectively. (B-D) Bar graphs show the distance traveled in OFT, the time spent in the central partition, and the time in open arms of EPM in control mice and MPTP-mice treated with BLA-injection of muscimol (mus), SKF38393 (SKF), quinpirole (quin) or PMA. Two-way ANOVA, (C) MPTP:

$F_{(1,69)}=16.534, p<0.001$; drugs: $F_{(1,69)}=22.817, p=0.008$, (D) MPTP: $F_{(1,69)}=9.881, p=0.002$; drugs: $F_{(1,69)}=7.596, p=0.007 . * * p<0.01$ vs. control mice; $\#<0.05$ and $\# \#<0.01$ vs. MPTP-mice.

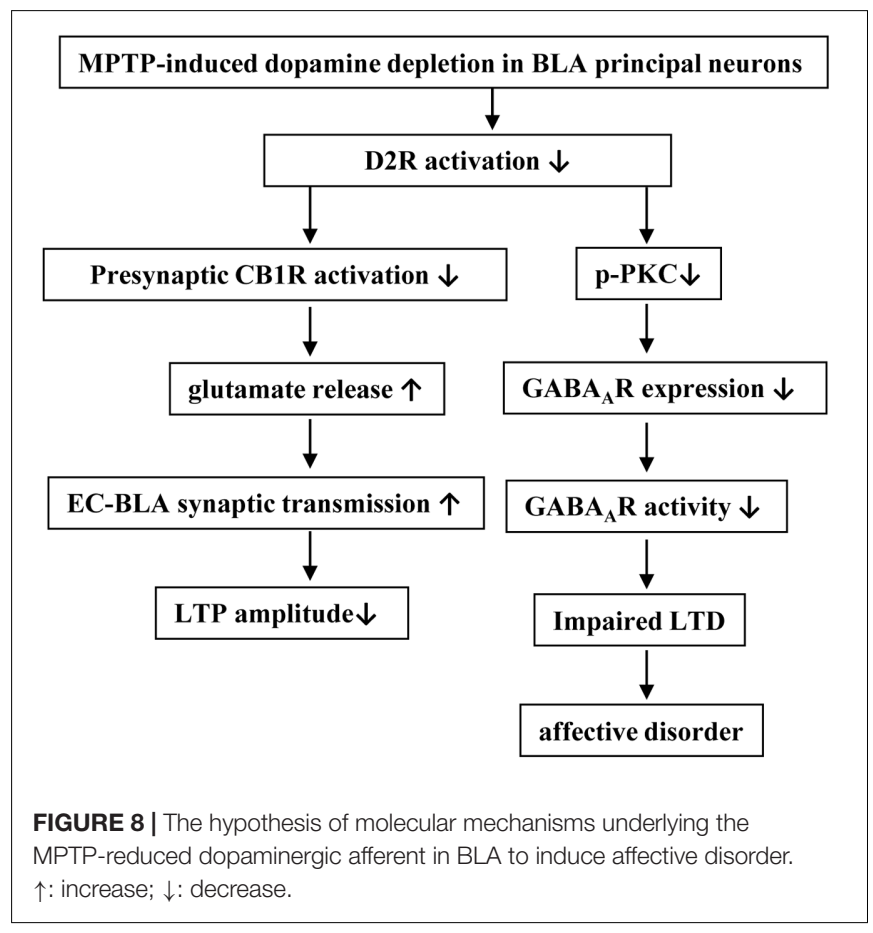

mice, the application of D2R or CB1R antagonist was able to increase the fEPSP slopes with decrease in the PPF value. And also, the effects of D2R antagonist on the fEPSP slopes and PPF value were blocked by the $\mathrm{CB} 1 \mathrm{R}$ agonist. The results indicate that the block of D2R in BLA principal neurons through reducing release of post-synaptic endocannabinoids causes the inactivation of presynaptic CB1R to enhance the glutamate release. In MPTPmice, the EC-BLA synaptic efficiency was enhanced with the reduction of PPF, which was corrected by the activation of D2R or CB1R rather than D1R. In particular, the effect of D2R agonist on glutamate release in MPTP-mice was abolished by the blockade of CB1R. Thus, it is conceivable that the MPTPinduced dopamine depletion via the decrease of $\mathrm{D} 2 \mathrm{R}$ activation leads to the decline of post-synaptic endocannabinoids release, which enhances presynaptic glutamate release to potentiate the EC-BLA excitatory. On the other hand, a multi-spike waveform fEPSP was observed in MPTP-mice with prolonged fEPSP duration and increased PPI value, reflecting a deficit in the GABAergic inhibition circuit (Delaney and Sah, 2001). The activation of presynaptic CB1R has been reported to inhibit the GABA release (Foldy et al., 2006). Interestingly, the BLAinjection of the $\mathrm{D} 2 \mathrm{R}$ agonist for 2 days could recover the $\mathrm{GABA}_{\mathrm{A}} \mathrm{R}$-mediated inhibition, but the bath-application of the D2R agonist had no effects. Therefore, it is indicated that the MPTP-induced dopamine depletion via the decrease of D2R activation reduces the $G_{A B A} R$ expression rather than the GABA release leading to the deficits in the BLA inhibitory circuits.

The LTP induction at BLA glutamatergic synapses depends on the $\mathrm{Ca}^{2+}$ influx from the NMDA receptor (Mirante et al., 2014). A possible explanation for the decreased amplitude of LTP in MPTP-mice is that the increased glutamate release causes NMDA receptor activation prior to LTP induction, which elicits presynaptic inhibition when LTP is induced through releasing retrograde factor(s) (Kato et al., 1999). This idea is supported by our experimental results that the bath-application of D2R agonist recovered the normal LTP amplitude in MPTP-mice. 
Additionally, the PKA signaling is involved in the induction of LTP at the cortical input to the lateral amygdala synapses (Fourcaudot et al., 2008). Although the D1R agonist recovered the phospho-PKA in MPTP-mice, it did not correct the LTP amplitude. The GABAergic inhibitory circuit in BLA is very important for the LTD induction (Rammes et al., 2001) and controlling motion and attention behavior (Martijena et al., 2002). The GABAergic system in the amygdala networks appears to be involved in generating responses to fear-conditioned stimuli (Ehrlich et al., 2009) and is crucial for processes of fear extinction learning (Sangha et al., 2009). The impairment of LTD in MPTPmice was rescued by the bath-application of the $\mathrm{GABA}_{\mathrm{A}} \mathrm{R}$ agonist or the BLA-injection of the $\mathrm{D} 2 \mathrm{R}$ agonist or the $\mathrm{PKC}$ activator. Consistently, the anxiety-like behaviors in MPTP-mice were improved by the BLA-injection of the $\mathrm{GABA}_{\mathrm{A}} \mathrm{R}$ and $\mathrm{D} 2 \mathrm{R}$ agonists or PKC activator. Thus, the MPTP-impaired LTD induction in the BLA is likely responsible for the production of anxiety-like behaviors.

The results from the present study indicate that the MPTPinduced dopamine depletion via the decrease of $\mathrm{D} 2 \mathrm{R}$ activation in BLA principal neurons suppresses $\mathrm{GABA}_{\mathrm{A}} \mathrm{R}$ expression and activity, which impairs LTD induction leading to the production of anxiety-like behaviors (Figure 8). The present study provides

\section{REFERENCES}

Abramian, A. M., Comenencia-Ortiz, E., Vithlani, M., Tretter, E. V., Sieghart, W., Davies, P. A., et al. (2010). Protein kinase C phosphorylation regulates membrane insertion of GABAA receptor subtypes that mediate tonic inhibition. J. Biol. Chem. 285, 41795-41805. doi: 10.1074/jbc.M110.149229

An, J. J., Bae, M. H., Cho, S. R., Lee, S. H., Choi, S. H., Lee, B. H., et al. (2004). Altered GABAergic neurotransmission in mice lacking dopamine D2 receptors. Mol. Cell Neurosci. 25, 732-741. doi: 10.1016/j.mcn.2003.12.010

Barbalho, C. A., Nunes-de-Souza, R. L., and Canto-de-Souza, A. (2009). Similar anxiolytic-like effects following intra-amygdala infusions of benzodiazepine receptor agonist and antagonist: evidence for the release of an endogenous benzodiazepine inverse agonist in mice exposed to elevated plus-maze test. Brain Res. 1267, 65-76. doi: 10.1016/j.brainres.2009.02.042

Bissière, S., Humeau, Y., and Lüthi, A. (2003). Dopamine gates LTP induction in lateral amygdala by suppressing feedforward inhibition. Nat. Neurosci. 6, 587-592.

Bohnsack, J. P., Carlson, S. L., and Morrow, A. L. (2016). Differential regulation of synaptic and extrasynaptic alpha4 GABA(A) receptor populations by protein kinase A and protein kinase $\mathrm{C}$ in cultured cortical neurons. Neuropharmacology 105, 124-132. doi: 10.1016/j.neuropharm.2016.01.009

Braak, H., Del Tredici, K., Rub, U., de Vos, R. A., Jansen Steur, E. N., and Braak, E. (2003). Staging of brain pathology related to sporadic Parkinson's disease. Neurobiol. Aging 24, 197-211.

Calon, F., Goulet, M., Blanchet, P. J., Martel, J. C., Piercey, M. F., Bedard, P. J., et al. (1995). Levodopa or D2 agonist induced dyskinesia in MPTP monkeys: correlation with changes in dopamine and GABAA receptors in the striatopallidal complex. Brain Res. 680, 43-52.

Crocker, S. J., Smith, P. D., Jackson-Lewis, V., Lamba, W. R., Hayley, S. P., Grimm, E., et al. (2003). Inhibition of calpains prevents neuronal and behavioral deficits in an MPTP mouse model of Parkinson's disease. J. Neurosci. 23, 4081-4091.

Dallerac, G. M., Vatsavayai, S. C., Cummings, D. M., Milnerwood, A. J., Peddie, C. J., Evans, K. A., et al. (2011). Impaired long-term potentiation in the prefrontal cortex of Huntington's disease mouse models: rescue by D1 dopamine receptor activation. Neurodegener. Dis. 8, 230-239. doi: 10.1159/ 000322540 insight into the mechanisms underlying anxiety disorders commonly observed in PD patients and potential therapeutic targets.

\section{AUTHOR CONTRIBUTIONS}

TZ and PC performed the field potential recording, immunostaining, western blotting, and all statistical analysis. TC and BZ undertook the whole cell patch-clamp recording and RT-PCR analysis. JH carried out the animal care and behavioral examination. LC designed the experiment and finished the manuscript.

\section{FUNDING}

This study was supported by the National Natural Science Foundation of China $(81471157 ; 81671253)$, the National 973 Basic Research Program of China (2014CB943303), Jiangsu provincial Science Foundation (EB2016765), and Postgraduate Research \& Practice Innovation Program of Jiangsu Province (KYCX17_1266).

Dalton, G. L., Wu, D. C., Wang, Y. T., Floresco, S. B., and Phillips, A. G. (2012). NMDA GluN2A and GluN2B receptors play separate roles in the induction of LTP and LTD in the amygdala and in the acquisition and extinction of conditioned fear. Neuropharmacology 62, 797-806. doi: 10.1016/j.neuropharm. 2011.09.001

de la Mora, M. P., Gallegos-Cari, A., Arizmendi-Garcia, Y., Marcellino, D., and Fuxe, K. (2010). Role of dopamine receptor mechanisms in the amygdaloid modulation of fear and anxiety: structural and functional analysis. Prog. Neurobiol. 90, 198-216. doi: 10.1016/j.pneurobio.2009.10.010

Delaney, A. J., and Sah, P. (2001). Pathway-specific targeting of GABA(A) receptor subtypes to somatic and dendritic synapses in the central amygdala. J. Neurophysiol. 86, 717-723.

Diaz, M. R., Chappell, A. M., Christian, D. T., Anderson, N. J., and McCool, B. A. (2011). Dopamine D3-like receptors modulate anxiety-like behavior and regulate GABAergic transmission in the rat lateral/basolateral amygdala. Neuropsychopharmacology 36, 1090-1103. doi: 10.1038/npp.2010.246

Ehrlich, I., Humeau, Y., Grenier, F., Ciocchi, S., Herry, C., and Luthi, A. (2009). Amygdala inhibitory circuits and the control of fear memory. Neuron 62, 757-771. doi: 10.1016/j.neuron.2009.05.026

Fadok, J. P., Dickerson, T. M., and Palmiter, R. D. (2009). Dopamine is necessary for cue-dependent fear conditioning. J. Neurosci. 29, 11089-11097. doi: 10.1523/ JNEUROSCI.1616-09.2009

Flores-Hernandez, J., Galarraga, E., and Bargas, J. (1997). Dopamine selects glutamatergic inputs to neostriatal neurons. Synapse 25, 185-195.

Foldy, C., Neu, A., Jones, M. V., and Soltesz, I. (2006). Presynaptic, activitydependent modulation of cannabinoid type 1 receptor-mediated inhibition of GABA release. J. Neurosci. 26, 1465-1469. doi: 10.1523/JNEUROSCI.4587-05. 2006

Fourcaudot, E., Gambino, F., Humeau, Y., Casassus, G., Shaban, H., Poulain, B., et al. (2008). cAMP/PKA signaling and RIM1alpha mediate presynaptic LTP in the lateral amygdala. Proc. Natl. Acad. Sci. U.S.A. 105, 15130-15135. doi: 10.1073/pnas.0806938105

Goosens, K. A., and Maren, S. (2002). Long-term potentiation as a substrate for memory: evidence from studies of amygdaloid plasticity and Pavlovian fear conditioning. Hippocampus 12, 592-599. doi: 10.1002/hipo.10099

Hong, S. I., Kwon, S. H., Hwang, J. Y., Ma, S. X., Seo, J. Y., Ko, Y. H., et al. (2016). Quinpirole increases melatonin-augmented pentobarbital sleep via cortical 
ERK, p38 MAPK, and PKC in mice. Biomol. Ther. 24, 115-122. doi: 10.4062/ biomolther.2015.097

Hong, Z., Tian, Y., Qi, M., Li, Y., Du, Y., Chen, L., et al. (2016). Transient receptor potential vanilloid 4 inhibits gamma-aminobutyric acid-activated current in hippocampal pyramidal neurons. Front. Mol. Neurosci. 9:77. doi: 10.3389/ fnmol.2016.00077

Isoardi, N. A., Martijena, I. D., Carrer, H. F., and Molina, V. A. (2004). Increased fear learning coincides with neuronal dysinhibition and facilitated LTP in the basolateral amygdala following benzodiazepine withdrawal in rats. Neuropsychopharmacology 29, 1852-1864. doi: 10.1038/sj.npp.1300478

Janssen, M. L., Temel, Y., Delaville, C., Zwartjes, D. G., Heida, T., De Deurwaerdere, P., et al. (2016). Cortico-subthalamic inputs from the motor, limbic, and associative areas in normal and dopamine-depleted rats are not fully segregated. Brain Struct. Funct. doi: 10.1007/s00429-016-1351-5 [Epub ahead of print].

Kato, K., Li, S. T., and Zorumski, C. F. (1999). Modulation of long-term potentiation induction in the hippocampus by N-methyl-D-aspartate-mediated presynaptic inhibition. Neuroscience 92, 1261-1272.

Kim, D. H., Jung, J. S., Kim, H. S., Suh, H. W., Son, B. K., Kim, Y. H., et al. (2000). Inhibition of brain protein kinase $\mathrm{C}$ attenuates immobilization stress-induced plasma corticosterone levels in mice. Neurosci. Lett. 291, 69-72.

Kim, J., Son, Y., Kim, J., Lee, S., Kang, S., Park, K., et al. (2015). Developmental and degenerative modulation of GABAergic transmission in the mouse hippocampus. Int. J. Dev. Neurosci. 47, 320-332. doi: 10.1016/j.ijdevneu.2015. 08.009

Kim, Y., Wang, W. Z., Comte, I., Pastrana, E., Tran, P. B., Brown, J., et al. (2010). Dopamine stimulation of postnatal murine subventricular zone neurogenesis via the D3 receptor. J. Neurochem. 114, 750-760. doi: 10.1111/j.1471-4159.2010. 06799.x

Kroner, S., Rosenkranz, J. A., Grace, A. A., and Barrionuevo, G. (2005). Dopamine modulates excitability of basolateral amygdala neurons in vitro. J. Neurophysiol. 93, 1598-1610. doi: 10.1152/jn.00843.2004

Lalchandani, R. R., van der Goes, M. S., Partridge, J. G., and Vicini, S. (2013). Dopamine D2 receptors regulate collateral inhibition between striatal medium spiny neurons. J. Neurosci. 33, 14075-14086. doi: 10.1523/JNEUROSCI.069213.2013

Li, Y. C., Kellendonk, C., Simpson, E. H., Kandel, E. R., and Gao, W. J. (2011). D2 receptor overexpression in the striatum leads to a deficit in inhibitory transmission and dopamine sensitivity in mouse prefrontal cortex. Proc. Natl. Acad. Sci. U.S.A. 108, 12107-12112. doi: 10.1073/pnas.1109718108

Marowsky, A., Fritschy, J. M., and Vogt, K. E. (2004). Functional mapping of GABA A receptor subtypes in the amygdala. Eur. J. Neurosci. 20, 1281-1289. doi: 10.1111/j.1460-9568.2004.03574.x

Martijena, I. D., Rodriguez Manzanares, P. A., Lacerra, C., and Molina, V. A. (2002). Gabaergic modulation of the stress response in frontal cortex and amygdala. Synapse 45, 86-94. doi: 10.1002/syn.10085

McDonald, A. J., and Mascagni, F. (2004). Parvalbumin-containing interneurons in the basolateral amygdala express high levels of the alphal subunit of the GABAA receptor. J. Comp. Neurol. 473, 137-146. doi: 10.1002/cne.20101

Mirante, O., Brandalise, F., Bohacek, J., and Mansuy, I. M. (2014). Distinct molecular components for thalamic- and cortical-dependent plasticity in the lateral amygdala. Front. Mol. Neurosci. 7:62. doi: 10.3389/fnmol.2014.00062

Muller, J. F., Mascagni, F., and McDonald, A. J. (2009). Dopaminergic innervation of pyramidal cells in the rat basolateral amygdala. Brain Struct. Funct. 213, 275-288. doi: 10.1007/s00429-008-0196-y

Nakamura, Y., Darnieder, L. M., Deeb, T. Z., and Moss, S. J. (2015). Regulation of GABAARs by phosphorylation. Adv. Pharmacol. 72, 97-146. doi: 10.1016/bs. apha.2014.11.008

Nasehi, M., Meskarian, M., Khakpai, F., and Zarrindast, M. R. (2016). Harmalineinduced amnesia: possible role of the amygdala dopaminergic system. Neuroscience 312, 1-9. doi: 10.1016/j.neuroscience.2015.11.004

Nishiyama, M., Togashi, K., Aihara, T., and Hong, K. (2010). GABAergic activities control spike timing- and frequency-dependent long-term depression at hippocampal excitatory synapses. Front. Synaptic Neurosci. 2:22. doi: $10.3389 /$ fnsyn. 2010.00022

Pan, B., Hillard, C. J., and Liu, Q. S. (2008). D2 dopamine receptor activation facilitates endocannabinoid-mediated long-term synaptic depression of GABAergic synaptic transmission in midbrain dopamine neurons via
cAMP-protein kinase A signaling. J. Neurosci. 28, 14018-14030. doi: 10.1523/ JNEUROSCI.4035-08.2008

Paxinos, G., and Franklin, K. B. J. (2004). The Mouse Brain in Stereotaxic Coordinates. New York, NY: Academic Press.

Ping, G., Qian, W., Song, G., and Zhaochun, S. (2014). Valsartan reverses depressive/anxiety-like behavior and induces hippocampal neurogenesis and expression of BDNF protein in unpredictable chronic mild stress mice. Pharmacol. Biochem. Behav. 124, 5-12. doi: 10.1016/j.pbb.2014.05.006

Pinto, A., and Sesack, S. R. (2008). Ultrastructural analysis of prefrontal cortical inputs to the rat amygdala: spatial relationships to presumed dopamine axons and D1 and D2 receptors. Brain Struct. Funct. 213, 159-175. doi: 10.1007/ s00429-008-0180-6

Prager, E. M., Bergstrom, H. C., Wynn, G. H., and Braga, M. F. (2016). The basolateral amygdala gamma-aminobutyric acidergic system in health and disease. J. Neurosci. Res. 94, 548-567. doi: 10.1002/jnr.23690

Rammes, G., Eder, M., Dodt, H. U., Kochs, E., and Zieglgansberger, W. (2001). Long-term depression in the basolateral amygdala of the mouse involves the activation of interneurons. Neuroscience 107, 85-97.

Rico, A. J., Dopeso-Reyes, I. G., Martinez-Pinilla, E., Sucunza, D., Pignataro, D., Roda, E., et al. (2017). Neurochemical evidence supporting dopamine D1D2 receptor heteromers in the striatum of the long-tailed macaque: changes following dopaminergic manipulation. Brain Struct. Funct. 222, 1767-1784. doi: 10.1007/s00429-016-1306-x

Rodriguez Manzanares, P. A., Isoardi, N. A., Carrer, H. F., and Molina, V. A. (2005). Previous stress facilitates fear memory, attenuates GABAergic inhibition, and increases synaptic plasticity in the rat basolateral amygdala. J. Neurosci. 25, 8725-8734. doi: 10.1523/JNEUROSCI.2260-05.2005

Rodriguez-Oroz, M. C., Jahanshahi, M., Krack, P., Litvan, I., Macias, R., Bezard, E., et al. (2009). Initial clinical manifestations of Parkinson's disease: features and pathophysiological mechanisms. Lancet Neurol. 8, 1128-1139. doi: 10.1016/ S1474-4422(09)70293-5

Rosenkranz, J. A., and Grace, A. A. (2002). Dopamine-mediated modulation of odour-evoked amygdala potentials during pavlovian conditioning. Nature 417, 282-287. doi: 10.1038/417282a

Sangha, S., Narayanan, R. T., Bergado-Acosta, J. R., Stork, O., Seidenbecher, T., and Pape, H. C. (2009). Deficiency of the $65 \mathrm{kDa}$ isoform of glutamic acid decarboxylase impairs extinction of cued but not contextual fear memory. J. Neurosci. 29, 15713-15720. doi: 10.1523/JNEUROSCI.2620-09.2009

Schober, A. (2004). Classic toxin-induced animal models of Parkinson's disease: 6-OHDA and MPTP. Cell Tissue Res. 318, 215-224. doi: 10.1007/s00441-0040938-y

Senn, V., Wolff, S. B., Herry, C., Grenier, F., Ehrlich, I., Grundemann, J., et al. (2014). Long-range connectivity defines behavioral specificity of amygdala neurons. Neuron 81, 428-437. doi: 10.1016/j.neuron.2013.11.006

Shin, K. S., Zhao, T. T., Choi, H. S., Hwang, B. Y., Lee, C. K., and Lee, M. K. (2014). Effects of gypenosides on anxiety disorders in MPTP-lesioned mouse model of Parkinson's disease. Brain Res. 1567, 57-65. doi: 10.1016/j.brainres.2014.04.015

Soghomonian, J. J., and Chesselet, M. F. (2000). GABA in the Basal Ganglia [J]. GABA in the Nervous System. Philadelphia, PA: Lippincott Williams and Wilkins, 265-291.

Soni, N., Satpathy, S., and Kohlmeier, K. A. (2014). Neurophysiological evidence for the presence of cannabinoid CB1 receptors in the laterodorsal tegmental nucleus. Eur. J. Neurosci. 40, 3635-3652. doi: 10.1111/ejn.12730

Trantham-Davidson, H., Neely, L. C., Lavin, A., and Seamans, J. K. (2004). Mechanisms underlying differential D1 versus D2 dopamine receptor regulation of inhibition in prefrontal cortex. J. Neurosci. 24, 10652-10659. doi: 10.1523/JNEUROSCI.3179-04.2004

von Bohlen und Halbach, O., Schober, A., Hertel, R., and Unsicker, K. (2005). MPTP treatment impairs tyrosine hydroxylase immunopositive fibers not only in the striatum, but also in the amygdala. Neurodegener. Dis. 2, 44-48. doi: $10.1159 / 000086430$

Walsh, K., and Bennett, G. (2001). Parkinson's disease and anxiety. Postgrad. Med. J. 77, 89-93.

Werner, D. F., Kumar, S., Criswell, H. E., Suryanarayanan, A., Fetzer, J. A., Comerford, C. E., et al. (2011). PKCgamma is required for ethanol-induced increases in $\mathrm{GABA}(\mathrm{A})$ receptor alpha4 subunit expression in cultured cerebral cortical neurons. J. Neurochem. 116, 554-563. doi: 10.1111/j.1471-4159.2010. 07140.x 
Woodruff, A. R., and Sah, P. (2007). Inhibition and synchronization of basal amygdala principal neuron spiking by parvalbumin-positive interneurons. J. Neurophysiol. 98, 2956-2961. doi: 10.1152/jn.00739.2007

Yamaguchi, T., Goto, A., Nakahara, I., Yawata, S., Hikida, T., Matsuda, M., et al. (2015). Role of PKA signaling in D2 receptor-expressing neurons in the core of the nucleus accumbens in aversive learning. Proc. Natl. Acad. Sci. U.S.A. 112, 11383-11388. doi: 10.1073/pnas.1514731112

Yin, H. H., and Lovinger, D. M. (2006). Frequency-specific and D2 receptormediated inhibition of glutamate release by retrograde endocannabinoid signaling. Proc. Natl. Acad. Sci. U.S.A. 103, 8251-8256. doi: 10.1073/pnas. 0510797103

Zeni, A. L., Zomkowski, A. D., Maraschin, M., Rodrigues, A. L., and Tasca, C. I. (2012). Involvement of PKA, CaMKII, PKC, MAPK/ERK and PI3K in the acute antidepressant-like effect of ferulic acid in the tail suspension test. Pharmacol. Biochem. Behav. 103, 181-186. doi: 10.1016/j.pbb.2012.08.020

Zhang, B., Wang, L., Chen, T., Hong, J., Sha, S., Wang, J., et al. (2017). Sigma-1 receptor deficiency reduces GABAergic inhibition in the basolateral amygdala leading to LTD impairment and depressive-like behaviors. Neuropharmacology 116, 387-398. doi: 10.1016/j.neuropharm.2017.01.014

Zhang, J., Huang, X. Y., Ye, M. L., Luo, C. X., Wu, H. Y., Hu, Y., et al. (2010) Neuronal nitric oxide synthase alteration accounts for the role of 5-HT1A receptor in modulating anxiety-related behaviors. J. Neurosci. 30, 2433-2441. doi: 10.1523/JNEUROSCI.5880-09.2010

Zhang, T., Hong, J., Di, T., and Chen, L. (2016). MPTP impairs dopamine D1 receptor-mediated survival of newborn neurons in ventral hippocampus to cause depressive-like behaviors in adult mice. Front. Mol. Neurosci. 9:101 doi: 10.3389/fnmol.2016.00101

Zhou, L., Chen, T., Li, G., Wu, C., Wang, C., Li, L., et al. (2016). Activation of PPARgamma ameliorates spatial cognitive deficits through restoring expression of AMPA receptors in seipin knock-out mice. J. Neurosci. 36, 1242-1253. doi: 10.1523/JNEUROSCI.3280-15.2016

Conflict of Interest Statement: The authors declare that the research was conducted in the absence of any commercial or financial relationships that could be construed as a potential conflict of interest.

Copyright (c) 2017 Zhang, Chen, Chen, Zhang, Hong and Chen. This is an open-access article distributed under the terms of the Creative Commons Attribution License (CC BY). The use, distribution or reproduction in other forums is permitted, provided the original author(s) or licensor are credited and that the original publication in this journal is cited, in accordance with accepted academic practice. No use, distribution or reproduction is permitted which does not comply with these terms. 